\title{
Catalyzed and uncatalyzed procedures for the syntheses of isomeric covalent multi-indolyl hetero non-metallides: an account
}

\author{
Ranadeep Talukdar
}

\author{
Review \\ Address: \\ Department of Chemistry, Indian Institute of Technology Kharagpur, \\ West Midnapore, West Bengal - 721302, India \\ Email: \\ Ranadeep Talukdar - ranadeep@chem.iitkgp.ernet.in \\ Keywords: \\ bisindole; heteroatom; indole; selenide; sulfide
}

\author{
Beilstein J. Org. Chem. 2021, 17, 2102-2122. \\ https://doi.org/10.3762/bjoc.17.137 \\ Received: 12 May 2021 \\ Accepted: 02 August 2021 \\ Published: 19 August 2021 \\ Associate Editor: J. A. Murphy \\ (c) 2021 Talukdar; licensee Beilstein-Institut. \\ License and terms: see end of document.
}

\begin{abstract}
Two or more indole molecules tailored to a single non-metal central atom, through any of their C2-7 positions are not only structurally engaging but also constitute a class of important pharmacophores. Although the body of such multi-indolyl non-metallide molecules are largely shared to the anticancer agent bis(indolyl)methane, other heteroatomic analogs also possess similar medicinal properties. This concise review will discuss various catalytic and uncatalytic synthetic strategies adopted for the synthesis of the non-ionic (non-metallic) versions of these important molecules till date.
\end{abstract}

\section{Introduction}

Indole can be considered as a "prodigy" in the family of nitrogen-based heterocycles, because of its diverse presence in bioactive molecules [1-8], coupled with the distinct nucleophilic chemistry revolving its aromatic benzo-fused pyrrole system as encountered throughout the bibliography [9-15]. It is therefore obvious that a non-metal hydride will become exceptionally crucial when its hydrogen atoms are replaced by this special heterocycle, forming a multi-indolyl hetero non-metallide. In contemporary period, the said molecules have earned extensive importance in pharmacology to prevent cancer of a number of human organs, certified by the recent flooding of scientific literature related to bis(indolyl)methanes, which shows the usefulness of this class of molecules for prevention of this terminal disease [16-23]. Related molecules consisting of heteroatoms at the central tethering position have also appeared in the spotlight of anticancer research recently. In line with this high importance associated with the molecules of current topic, i.e., more than one indole molecule flanked by a central atom, conglomeration of the available synthetic methods will have a high scientific value. This review will give a concise account of the same, although preparations of ionic bis(indolyl) metal salts will not be considered [24-33].

\section{Review}

The pyrrole C2 and C3 linkages

By virtue of the two available sites in its pyrrole substructure, two indoles can be attached to a central atom via their C-2 or $\mathrm{C}-3$ positions in a symmetric way. The non-symmetric variety 
may connect them with $\mathrm{C}-2$ of one with the $\mathrm{C}-3$ of another, via the central atom. Below described are such synthetic strategies which are classified depending on the central tethering atom, largely with boron, carbon, nitrogen, oxygen, silicon, phosphorus, sulfur, selenium, and tellurium. This review will skip the reports on the corresponding carbon-centered analogs.

\section{Boranes}

First discovered in 1894 [34], 2,2'-bisarylborinates are used for treating prostate cancers utilizing their property of inhibiting the transient receptor potential channels such as TRPM-7 [35]. In 2015, Murakami synthesized the novel indole C-2 borinic acid derivative 3 by reacting $N$-methylindole (1) with triisopropyl borate (2) in a strongly basic medium (Scheme 1). The product formation proceeds through the indole $\mathrm{C}-2$ deprotonation mechanism [36].

The reason behind the $\mathrm{C}-2$ attachment of the boron atom rather than at the $\mathrm{C}-3$ position of the indole ring was explained by McGough et al. [37]. They performed a base-free catalytic $\mathrm{I}_{2}$-assisted indole $\mathrm{C}-\mathrm{H}$ functionalization (electrophilic borylation) using the $N$-protected indole $\mathbf{1}$ and NHC borane $4 \mathbf{a}$ that gave a mixture of the mono and bis isomers ( 5 and $\mathbf{6}$, respectively) in fair to excellent yields (Scheme 2a). Increasing the amount of iodine led to less unreacted starting material $\mathbf{1}$, and increased formation of the bisindole product $\mathbf{6}$. An almost quantitative conversion of $\mathbf{1}$ was observed with a high excess of the indole reactant.

Murakami, 2015 [36]
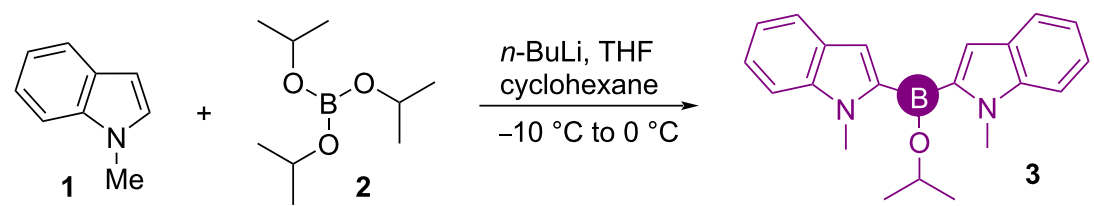

Scheme 1: Synthesis of 2,2'-bis(indole)borinic ester 3.

a) McGough, 2017 [37]<smiles></smiles>

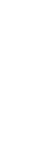<smiles>Cn1ccc2ccccc21</smiles>

1, $x$ equiv

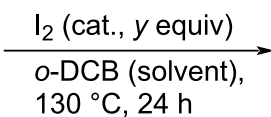
$130{ }^{\circ} \mathrm{C}, 24 \mathrm{~h}$

$x=1.25$ equiv, $y=5.0 \mathrm{~mol} \%$, mono $/$ bis $=83: 17$, conversion $57 \%$ (mono + bis) $x=1.25$ equiv, $y=10.0 \mathrm{~mol} \%$, mono/bis $=73: 27$, conversion $69 \%$ (mono + bis) $x=7.0$ equiv, $y=10.0 \mathrm{~mol} \%$, mono $/$ bis $=60: 40$, conversion $99 \%$ (mono + bis)

b)<smiles></smiles><smiles></smiles><smiles>[BH3-]C1CCCC1</smiles><smiles>IC1CCCCC1</smiles>
$\mathrm{R}$

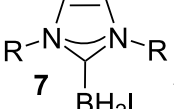<smiles>[3H]C([3H])C(C)C</smiles>

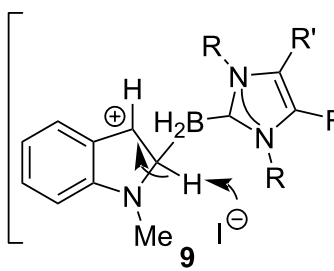<smiles></smiles><smiles></smiles>
bis) 
It is seen that in the presence of a base the C-2 deprotonation becomes very fast in $\mathbf{9}$ (for regaining aromaticity) so the boron at the initial C-3-borylated intermediate 8 (formed via $\mathrm{S}_{\mathrm{E}} \mathrm{Ar}$ ) cannot migrate fast enough, leading to a $\mathrm{C}-3$ borylation product 10a (unlike Pd) [38-40]. Here the absence of the base resulted in a slow or no $\mathrm{C}-2$ deprotonation of $\mathbf{9}$, which in turn forces the boron to migrate to $\mathrm{C}-2$ from $\mathrm{C}-3(\mathbf{8}$, Scheme $2 \mathrm{~b})$ to result in the C-2 borylation (10b).

\section{Amines}

Bis(indolyl)amines have recently become important as organic electroluminescent materials [41]. Hongtao and co-workers reported the synthesis of tetrakisindole species $\mathbf{1 3}$ through the coupling of aniline (12) and indole-2-boronic acid pinacol ester 11 using the Buchwald-Hartwig method (Scheme 3a) [42]. In a similar fashion, Han reported the syntheses of the symmetric and unsymmetric triaryl-substituted amines 15, 18, and 20 [43] Taking aniline as the pivotal moiety, it was coupled with isomeric bromoindoles $\mathbf{1 4}$ and $\mathbf{1 6}$ for the synthesis of the targeted products (Scheme $3 \mathrm{~b}$ ).

\section{Ethers}

Hongtao and co-workers also studied the electroluminescence properties of the 3,3'-bis(indolyl) ether derivatives $\mathbf{2 3}, \mathbf{2 6}$, and 28. The materials were prepared by the $\mathrm{Pd}(0)$-mediated coupling of lithium $\mathrm{N}$-arylindole-3-alkoxide 21 with 3-bromo- $N$ arylindole 22, followed by a further C-2 bromination (24) and subsequent Suzuki reaction with boronic acids 27 or 25 (Scheme 4) [42]. A similar class of molecules have found broad applications in organic electroluminescent devices [44].

\section{Silanes}

Heteroaryl compounds containing silicon, an earth abundant and non-toxic element, are important in organic electronics or photonics and in the field of drug discovery and nuclear medicine [45-50].

The first property could be attributed to the facile orbital interactions of the $\sigma^{*}$ orbital of silicon and the $\pi^{*}$ orbital of the butadiene unit, which overall lowers the energy of the LUMO [51,52]. Known previously with expensive transition-metal

a) Hongtao, 2015 [42]
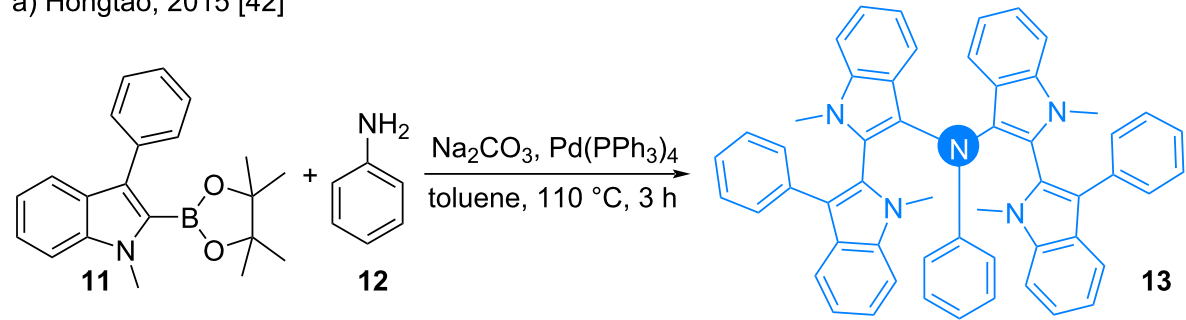

b) Han, 2016 [43]

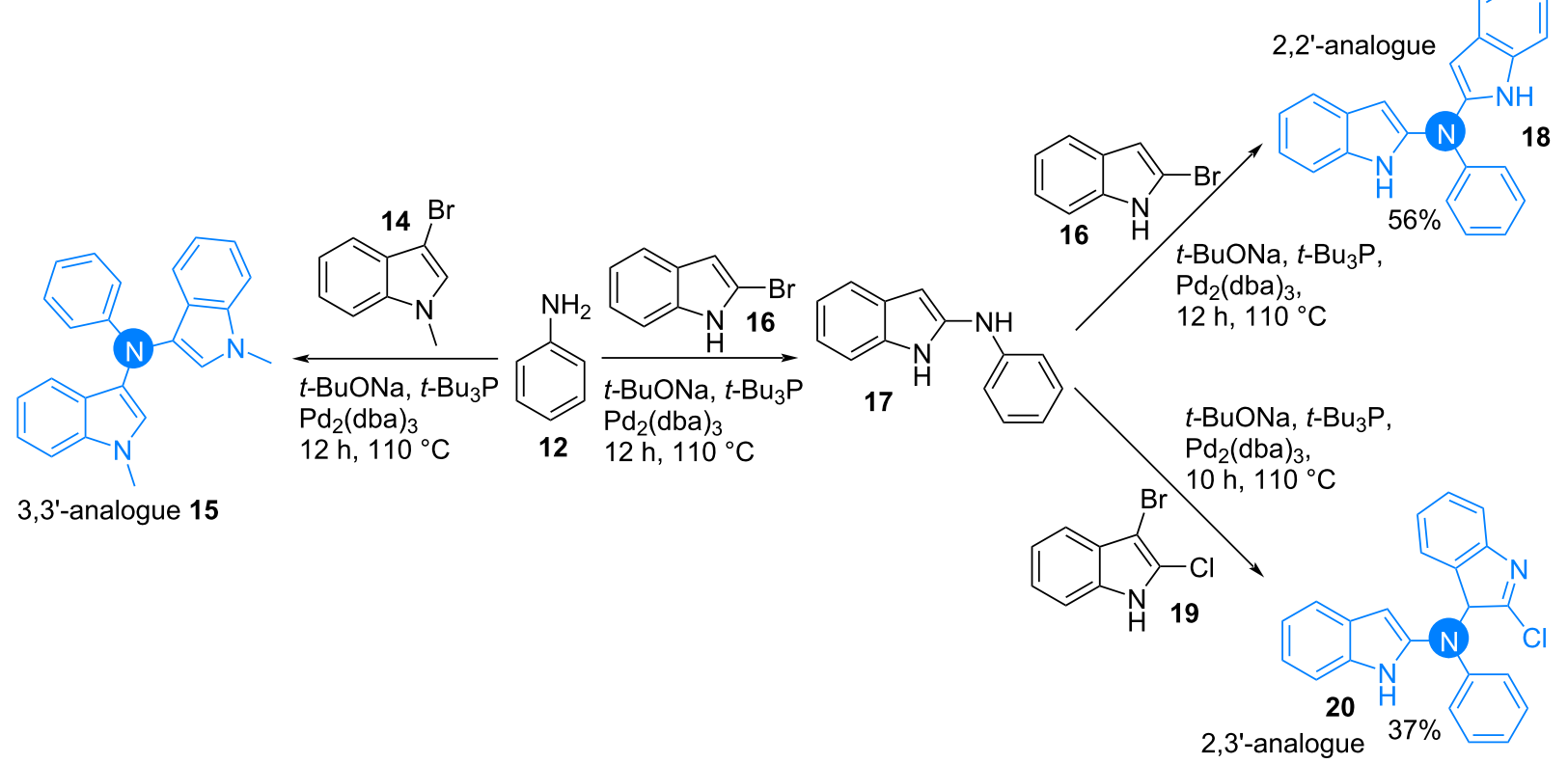


Hongtao, 2015 [42]<smiles>[GeH2]Oc1cn(-c2ccccc2)c2ccccc12</smiles><smiles>CC(C)(C)CC(C)(C)C(C)(C)C</smiles><smiles>c1ccc(-n2cc(COc3cn(-c4ccccc4)c4ccccc34)c3ccccc32)cc1</smiles>

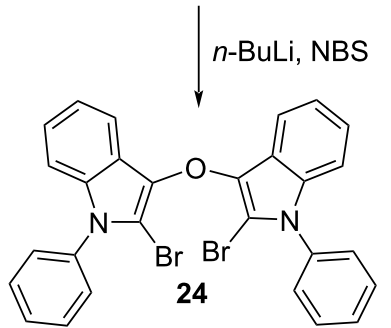
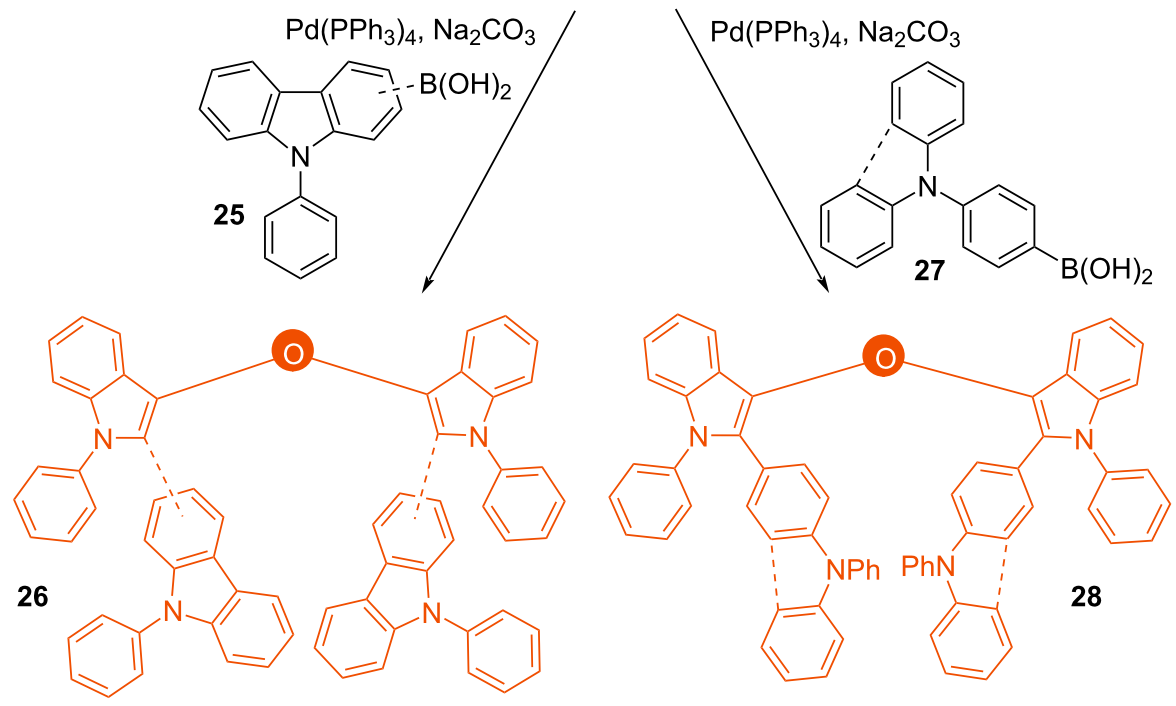

Scheme 4: Synthesis of 3,3'-bis(indolyl) ethers.

catalyst (Ru) [53], Grubbs demonstrated the first $\mathrm{KO} t$-Bu-catalyzed $\mathrm{C} 2-\mathrm{H}$ silylation of $\mathrm{N}$-methylindole (1) with observed $\mathrm{H}_{2}$ evolution [54]. Here the di(indol-2-yl)silane (31) was found as a minor product though (Scheme 5a). The reaction has a high turnover number of 92 and it was halted in the presence of radical scavengers. However, the mechanism was unidentified,

a) Grubbs, 2015 [54]<smiles>Cn1ccc2ccccc21</smiles>

1
$t$-BuOK $(20 \mathrm{~mol} \%)$

$\mathrm{Et}_{2} \mathrm{SiH}_{2}$ (29, 3 equiv)

THF, $45^{\circ} \mathrm{C}, 3$ days $-\mathrm{H}_{2}$

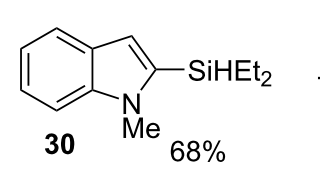

$t$-BuLi, THF, $\mathrm{Ph}_{2} \mathrm{SiCl}_{2}(33)$ b) Bell, 2017 [56]<smiles>Nc1ccccc1</smiles>

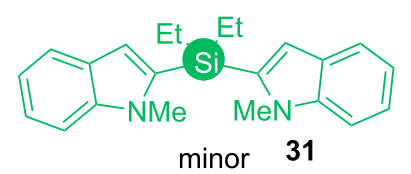

minor 31

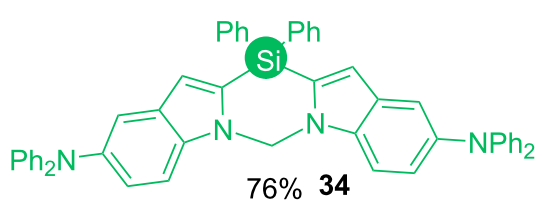


although it was proved to not going via a Minisci-type silyl radical addition [55], as the reaction with pyridine did not afford any product.

Bell studied the properties of such molecules which are similar to those used in OLED devices (organic light emitting diodes) in 2017. The molecule $\mathbf{3 4}$ was synthesized by base-mediated reaction of bisindole derivative 32 with $\mathrm{Ph}_{2} \mathrm{SiCl}_{2}(\mathbf{3 3}$, Scheme 5b) [56]. The dissociation of the indole C-2-Si bond upon UV light excitation generates a hole transport layer (HTL) in these materials, facilitating the optical activity [57].

In 1996, Frenzel reported the synthesis of bis(indol-3-yl)silane 38 that involved $n$-BuLi as the base [58]. The strategy was later adopted by Ohshita in 2004 (40a, Scheme 6) [59].

Between 2016 and 2018, some acid-catalyzed syntheses of bis(indol-3-yl)silanes appeared [60-63]. Chen and co-workers demonstrated a Brønsted acid-catalyzed Friedel-Crafts process, where hydrosilanes $\mathbf{4 1}$ were treated with an excess amount of indoles (Scheme 7a and Scheme 7b) [60]. Brookhart's acid $\left[\mathrm{H}\left(\mathrm{OEt}_{2}\right)_{2}\right]^{+}\left[\mathrm{BAr}^{\mathrm{F}}{ }_{4}\right]^{-}$(42) was used to generate ether-stabilized silicon cations of type $\mathbf{4 6}$ and norbornene was added as a proton scavenger [64]. Following this procedure, Yonekura synthesized the similar compound $\mathbf{4 0}$, using a catalytic Lewis acid $\mathrm{Zn}\left(\mathrm{NTf}_{2}\right)_{2}$ and stoichiometric Lewis base $\gamma$-picoline combination in $n$-butyronitrile as solvent (Scheme 7c) [61]. This electron-donating solvent and toluene in the former reaction acted as stabilizers to the electron-deficient silicon species in the similar mechanisms. First, the Brønsted or Lewis acid coordinates with silane 51 leading to a solvent-stabilized electron-deficient silane complex 57, where $N$-protected indole attacks in a Friedel-Crafts fashion to give the 3-silylindoles $\mathbf{6 0}$ along with molecular hydrogen (Scheme 7b and Scheme 7d). A repetition of the processes leads to the bis(indol-3-yl)silanes $\mathbf{4 0 .}$

Han described a Lewis acid-promoted C3-silylation of $\mathrm{N}$-protected substituted indoles by a disproportionation mechanism of the latter. He used both $\mathrm{B}\left(\mathrm{C}_{6} \mathrm{~F}_{5}\right)_{3}$ and $\mathrm{Al}\left(\mathrm{C}_{6} \mathrm{~F}_{5}\right)_{3}$ in the reactions (Scheme 8a and Scheme 8c) which followed a similar mechanism (Scheme 8b) $[62,63]$. The reduced form of indole, i.e., indoline $\mathbf{5 0}$ coordinates with the Lewis acid to form a complex which activates $\mathrm{PhSiH}_{3}$ (frustrated Lewis pair) for silylation $(\mathbf{6 9}$, Scheme $8 b)$.

\section{Phosphines}

The base-mediated syntheses of bis(indol-2-yl)phosphines 76 and $\mathbf{7 8}$ were demonstrated by $\mathrm{Yu}$. A suitable halophosphine $\mathbf{7 5}$ was reacted with $\mathrm{C} 2$-deprotonated $\mathrm{C} 3$-tethered (77) or untethered (74) $N$-protected indoles for that purpose (Scheme 9a) [65]. Later, Wassenaar reported a similar strategy with trichlorophosphine as the electrophile for attaching three indole moieties to a single P-atom (80, Scheme 9b) [66]. A similar protocol was adopted by van de Watering in their recent syntheses $[67,68]$.

\section{Sulfides}

The $\mathrm{C} 2$ tethering of indoles with sulfur can be achieved in neutral medium by treatment with various $\mathrm{SL}_{2}$ ( $\mathrm{L}$ is a leaving group) moieties $[69,70]$. This is a common method for the synthesis of bis(indol-2-yl)sulfides which are the precursors of potent bioactive molecules [71-73].

The simple synthetic strategies for the molecular units $\mathbf{8 2}$ were first reported by Barbier in 1989. The condensation of tryptamine monoacetate $(\mathbf{8 1 a})$ or indole oxime $(\mathbf{8 1 b})$ with sulfur dichloride in a Friedel-Crafts fashion (Scheme 10a) gave $\mathbf{8 2}$

a) Frenzel, 1996 [58]

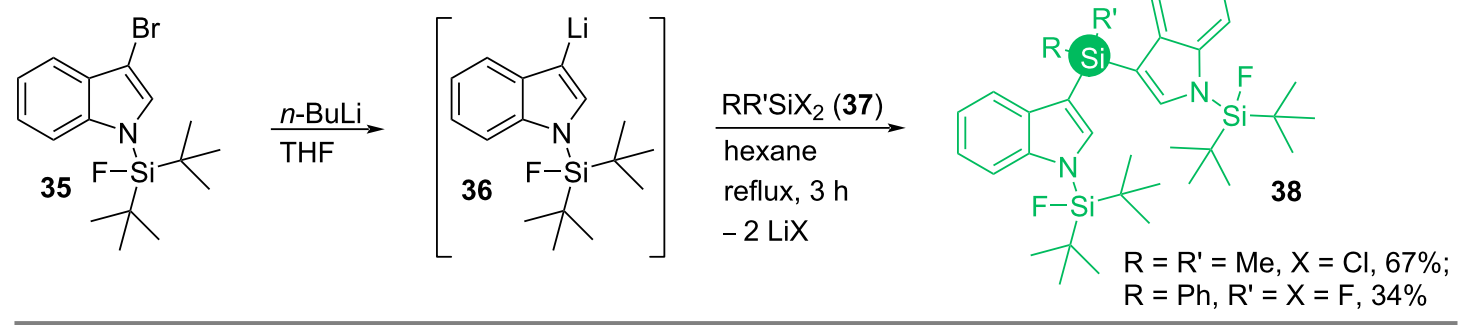

b) Ohshita, 2004 [59]

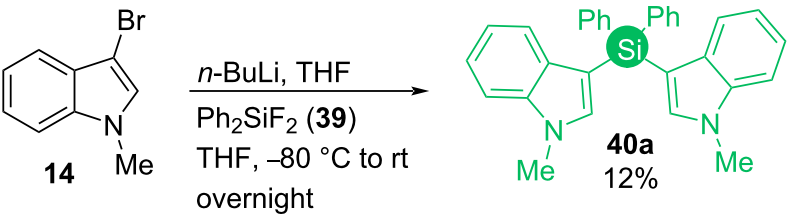


a) Chen, 2016 [60]

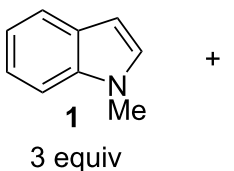

$\left[\mathrm{H}\left(\mathrm{OEt}_{2}\right)_{2}\right]^{+}\left[\mathrm{BArF}_{4}\right]^{-}(\mathbf{4 2}, 1 \mathrm{~mol} \%)$ norbornene ( 1.0 equiv)

41 1 equiv

toluene, rt, $18 \mathrm{~h},-\mathrm{H}_{2}$

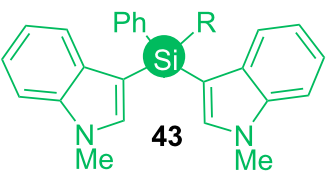

43a, $R=M e, 73 \%$;

43b, $R=H, 74 \%$

b)

$\mathrm{RR}^{\prime} \mathrm{SiH}_{2}$ (44)

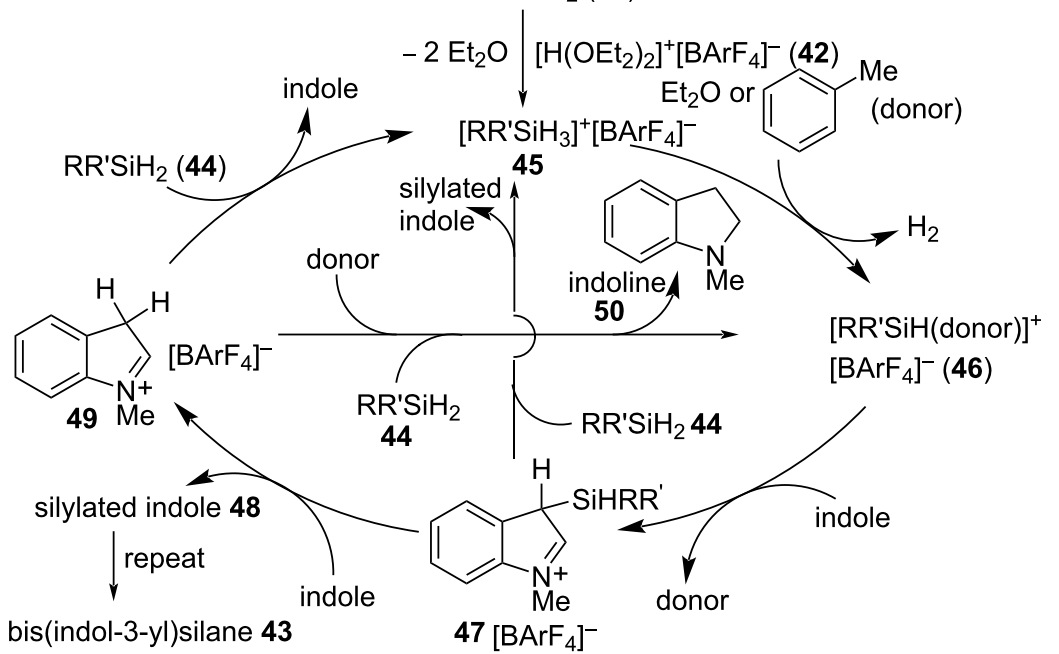

c) Yonekura, 2017 [61]
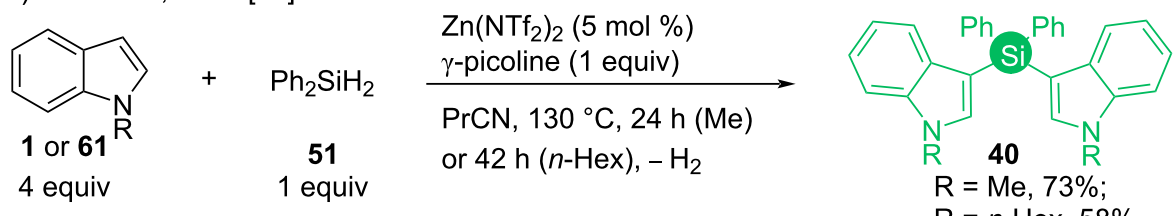

d)

$Z n^{\prime \prime}(\text { picoline })_{n+1}$

1) 52

40

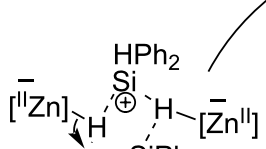

$\mathrm{SiHPh}_{2} \mathrm{Zn}^{\prime \prime}(\text { picoline })_{n}$

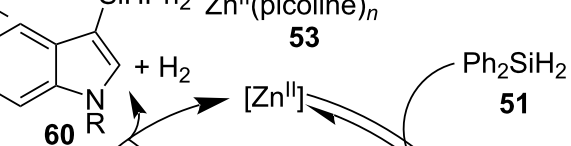

Scheme 7: Acid-catalyzed syntheses of bis(indol-3-yl)silanes and mechanisms. 

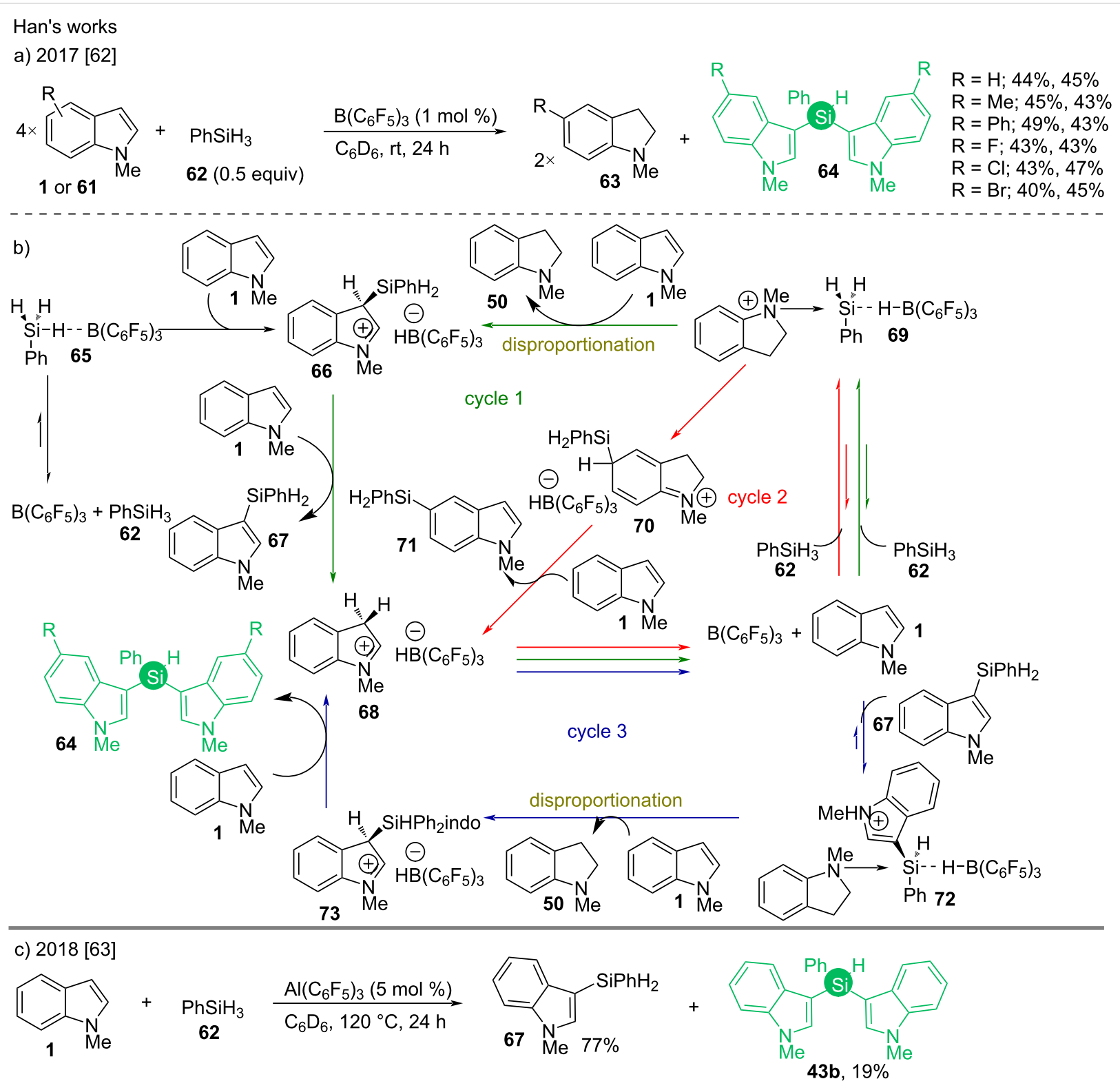

Scheme 8: $\mathrm{B}\left(\mathrm{C}_{6} \mathrm{~F}_{5}\right)_{3}$ and $\mathrm{Al}\left(\mathrm{C}_{6} \mathrm{~F}_{5}\right)_{3}$-catalyzed syntheses of bis(indol-3-yl)silanes reported by Han.

with moderate to good product yields, respectively [69,70]. A similar work by Janosik involved strongly basic conditions at low temperature with bis(phenylsulfonyl)sulfide $(\mathbf{8 3})$ as the sulfur donor (Scheme 10b) [73,74].

Disulfides are also important reagents for accessing bis(indolyl)sulfides. To synthesize the unsymmetrical bis(indolyl)sulfide $\mathbf{8 8}$, Janosik reacted the indole disulfide $\mathbf{8 7}$ with free indole and obtained the product $\mathbf{8 8}$ in $81 \%$ yield, where the sulfur linkages were $2,3^{\prime}$ - with respect to the two indole nuclei (Scheme 11a) [73-76]. Hall and Dockendorf prepared the corresponding 2,2'-sulfur-substituted compounds 90 by reacting tryptophan amines $\mathbf{8 9}$ and $\mathbf{9 0}$ with $\mathrm{S}_{2} \mathrm{Cl}_{2}$ under neutral and acidic conditions, respectively (Scheme 11b and Scheme 11c) [77,78].

Kamal took a different approach using a $\mathrm{CuO}$ nanoparticle-supported graphene-oxide (denoted as $\mathrm{CuO} @ \mathrm{GO}, 0.38 \mathrm{~mol} \%$ ) catalyzed $S$-arylation (C-S coupling) of 2-iodoindole (92) to synthesize diindol-2-ylsulfide (84) in 75\% yield (Scheme 12) [79]. Here 1.5 equivalents of thiourea acted as the sulfur source.

Bis(indol-3-yl)sulfides are also present as structural motifs in important organic compounds having semiconductor properties [80]. The syntheses of these compounds were studied by Janosik in 2006. The $N$-silyl-protected 3-bromoindole 93 was 
a) $\mathrm{Yu}, 2005$ [65]

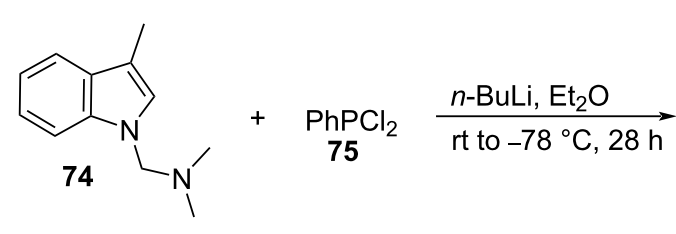<smiles>Cc1c(CPc2ccccc2)n(CN(C)C)c2ccccc12</smiles>

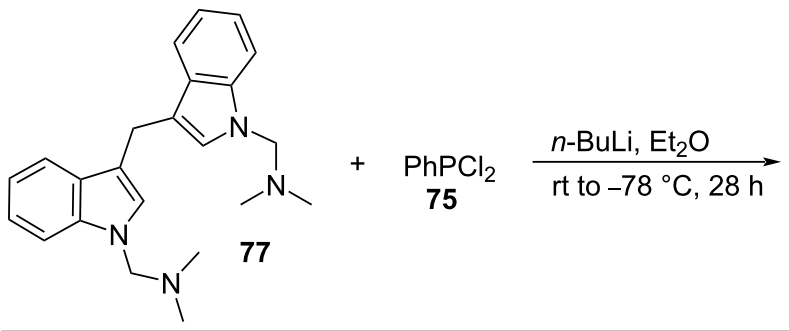

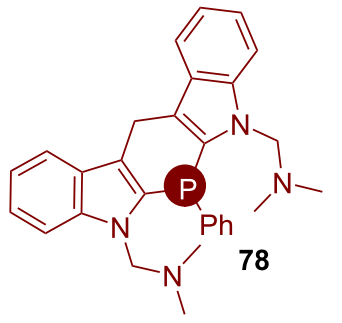

b) Wassenaar, 2010 [66]
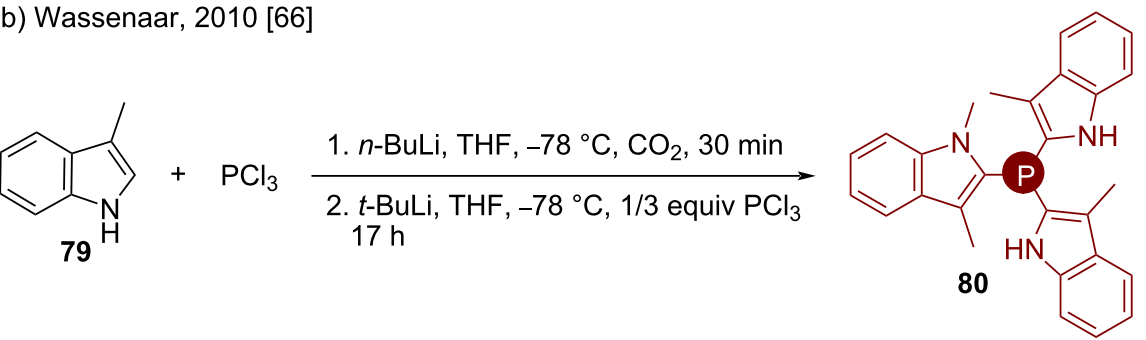

Scheme 9: Base-mediated syntheses of bis and tris(indol-2-yl)phosphines.

a) Barbier, 1989 [69]<smiles>[R]c1c[nH]c2ccccc12</smiles>

$+\quad \mathrm{SCl}_{2}$ $\underset{\text { solvent, temperature }}{\longrightarrow}$

81

$\mathrm{R}=-\mathrm{CH}_{2} \mathrm{CH}_{2} \mathrm{NHCCOCH}_{3} \mathrm{CHCl}_{3}, 2 \mathrm{~h}, \mathrm{rt}, 40 \%, 82 \mathrm{a}$ $\mathrm{R}=-\mathrm{C}=\mathrm{N}-\mathrm{OH}$ (oxime), $3 \mathrm{~h}, \mathrm{CH}_{3} \mathrm{CO}_{2} \mathrm{H}, \mathrm{rt}, 67 \%, \mathbf{8 2 b}$

b) Janosik, 2009 [73]

1) $n$-BuLi, THF, $-78^{\circ} \mathrm{C}$

2) $\mathrm{CO}_{2}-78{ }^{\circ} \mathrm{C}$<smiles>c1ccc2[nH]ccc2c1</smiles>

3) $t$-BuLi, $-78^{\circ} \mathrm{C}$

4) $\left(\mathrm{PhSO}_{2}\right)_{2} \mathrm{~S}(83)$, rt

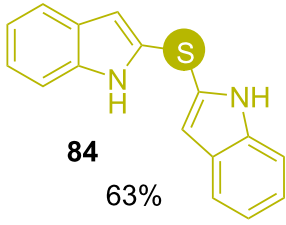

Janosik, 2007 [74]<smiles>O=S1(=O)NC=C(C2OCCO2)c2ccccc21</smiles>

LDA, THF, $-78^{\circ} \mathrm{C}, 0.5 \mathrm{~h}$ 2) $\left(\mathrm{PhSO}_{2}\right)_{2} \mathrm{~S}(83),-78^{\circ} \mathrm{C}$ to rt $16 \mathrm{~h}$

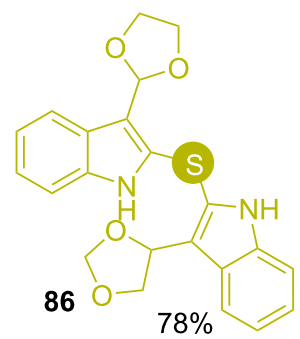

Scheme 10: Synthesis of bis(indol-2-yl)sulfides using $\mathrm{SL}_{2}$-type reagents. 
a) Janosik, 2002, 2006, 2007, 2009 [73-76]

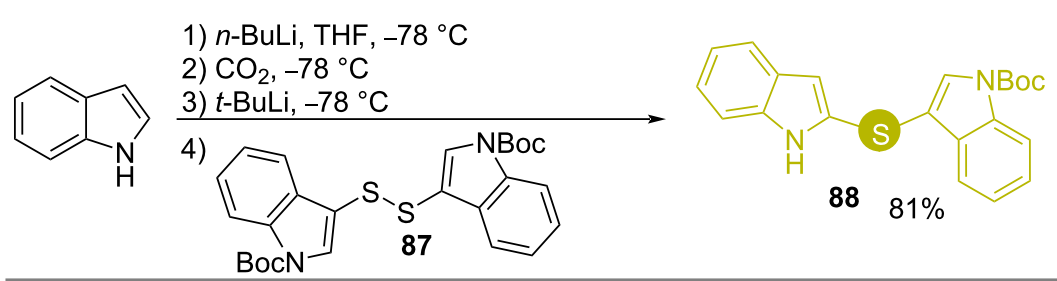

b) Hall, 2013 [77]
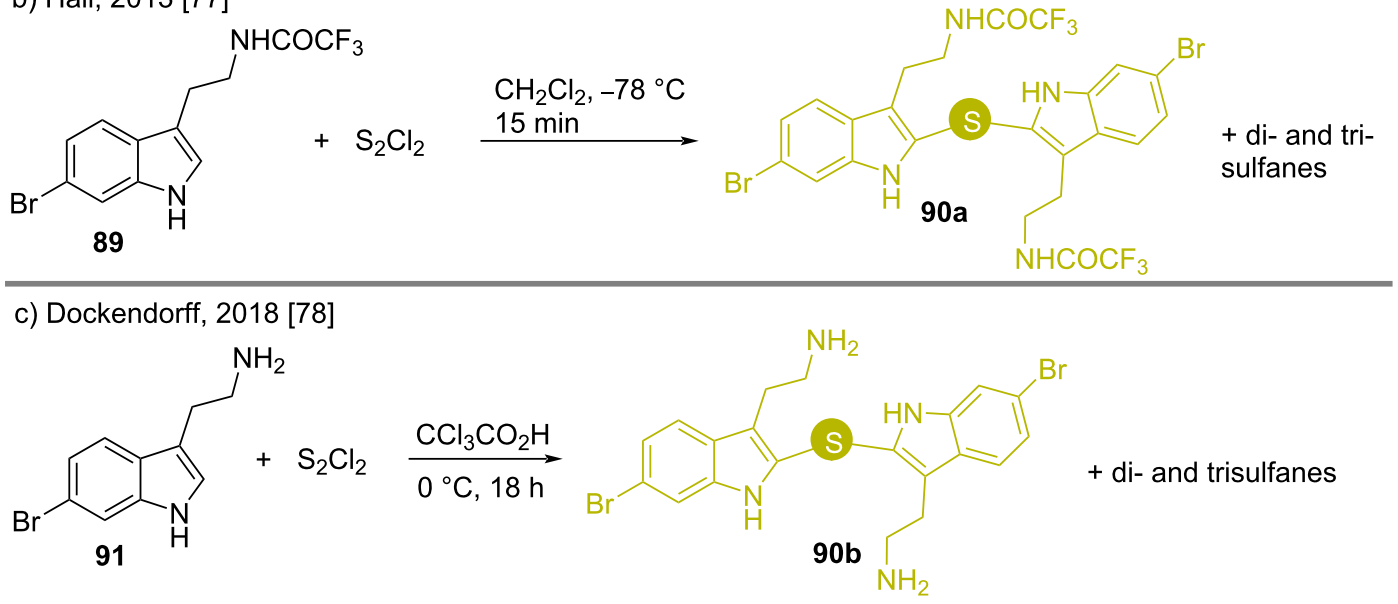

Scheme 11: Synthesis of 2,3'- and 2,2'-bis(indolyl)sulfides using disulfides as substrates.

Kamal, 2013 [79]
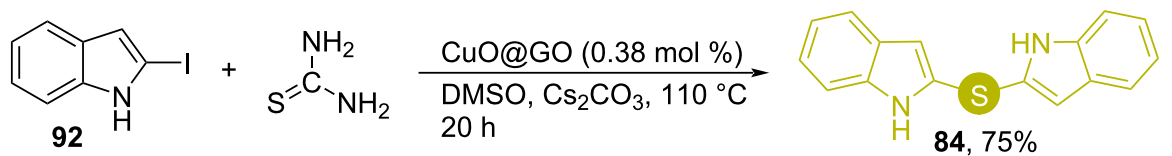

Scheme 12: Synthesis of diindol-2-ylsulfide (84) from 2-iodoindole (92) and thiourea.

subjected to strong basic medium ( $t$-BuLi) at low temperature and then quenched with either bis(phenylsulfonyl)sulfide (83) or indole disulfide 94 (Scheme 13) to afford the products 95 or 96, respectively [76].

Manishankar and co-workers dealt with a facile Fischer indole process to convert thiodiketones 97 to bis(indol-3-yl)sulfides 98 by refluxing them with phenylhydrazine hydrochloride salt in ethanol [81]. Interestingly, changing the solvent to THF switched the product to thioketone 99 (Scheme 14). Refluxing the thioketones 99 again with phenylhydrazine hydrochloride in ethanol resulted in the desired bis(indol-3-yl)sulfides 98. On the other hand, the treatment of thioketones 99 with phenylhydrazine afforded the corresponding hydrazones $\mathbf{1 0 0}$ only, thus stating the requirement of acid for this Fischer indole synthesis.

Elemental sulfur has also been utilized in preparing bis(indol-3yl)sulfides under transition-metal compound catalyzed sponta- neous oxidation of the central chalcogen atom. Such reactions were carried out by Shibahara (2014) and Yang (2016) [82,83]. Both reactions used aerial oxygen as the oxidizing agent for sulfur (Scheme 15). Shibahara utilized $20 \mathrm{~mol} \%$ copper(I) thiophene-2-carboxylate (CuTC) as the catalyst, where heating $\mathrm{N}$-methylindole (1) with elemental sulfur in DMSO as solvent at $90{ }^{\circ} \mathrm{C}$ under aerial oxygen led to the desired product $\mathbf{1 0 1}$ in $49 \%$ yield [82]. Other copper catalysts such as $\mathrm{CuCl}$ or $\mathrm{CuBr}$ gave low yields, even when used with 2,2'-bipyridyl as the ligand. First, oxidation of copper(I) takes place, which interacts with elemental sulfur to "activate" it. A nucleophilic attack from $N$-methylindole (1) to the sulfur species $\mathbf{1 0 2}$ takes place to generate copper sulfide complex 103. An oxidative homocoupling gives the bis(indol-3-yl)sulfide 101. Simultaneously, an oxidative homocoupling of the copper sulfide complex can take place to afford disulfide 104, that reacts with $N$-methylindole again under oxidative conditions, catalyzed by $\mathrm{CuTC}$ to give the desired product 101 (Scheme 15a). 


\section{Janosik, 2006 [76]}<smiles>CCn1cc(Br)c2ccccc21</smiles>

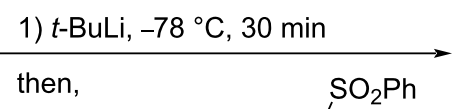
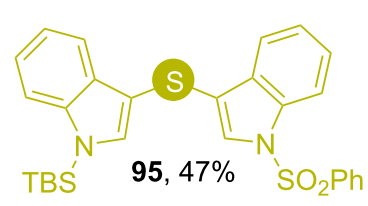

or

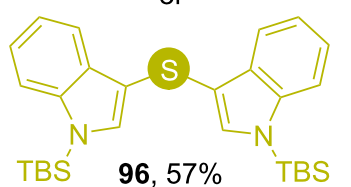

96, $57 \%$ 'TBS $\mathrm{PhO}_{2} \mathrm{~S}$

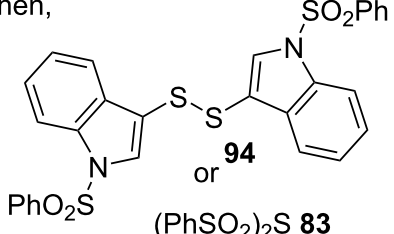

$\left(\mathrm{PhSO}_{2}\right)_{2} \mathrm{~S} 83$

$-78^{\circ} \mathrm{C}$ to rt, $16 \mathrm{~h}$

Scheme 13: Synthesis of bis(indol-3-yl)sulfides using $N$-silylated 3-bromoindole 93.

Manisankar, 2012 [81]<smiles>O=C([Ga])CSCC(=O)Br</smiles>

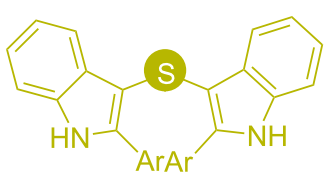

98
$\mathrm{Ar}=\mathrm{C}_{6} \mathrm{H}_{5}, 85 \% ; 4-\mathrm{MeC}_{6} \mathrm{H}_{4}, 81 \% ; 4-\mathrm{ClC}_{6} \mathrm{H}_{4}, 82 \%$;

4- $\mathrm{BrC}_{6} \mathrm{H}_{4}, 79 \%$; 4- $\mathrm{PhC}_{6} \mathrm{H}_{4}, 81 \%$; 2-naphthyl, 76\%

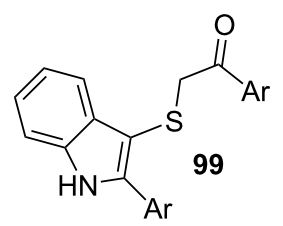

(solvent: THF)<smiles>O=C([Al])CSc1c(Br)[nH]c2ccccc12</smiles>

99

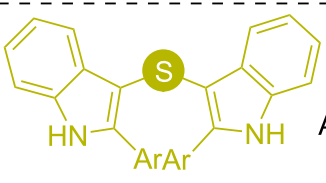

98<smiles>BrC(CSc1c(Br)[nH]c2ccccc12)=NNc1ccccc1</smiles>

$\mathrm{Ar}=4-\mathrm{MeC}_{6} \mathrm{H}_{4}, 79 \% ; 4-\mathrm{ClC}_{6} \mathrm{H}_{4}, 85 \%$; $4-\mathrm{BrC}_{6} \mathrm{H}_{4}, 83 \%$
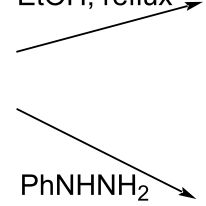

$\mathrm{EtOH}$, reflux 
a) Shibahara, 2014 [82]

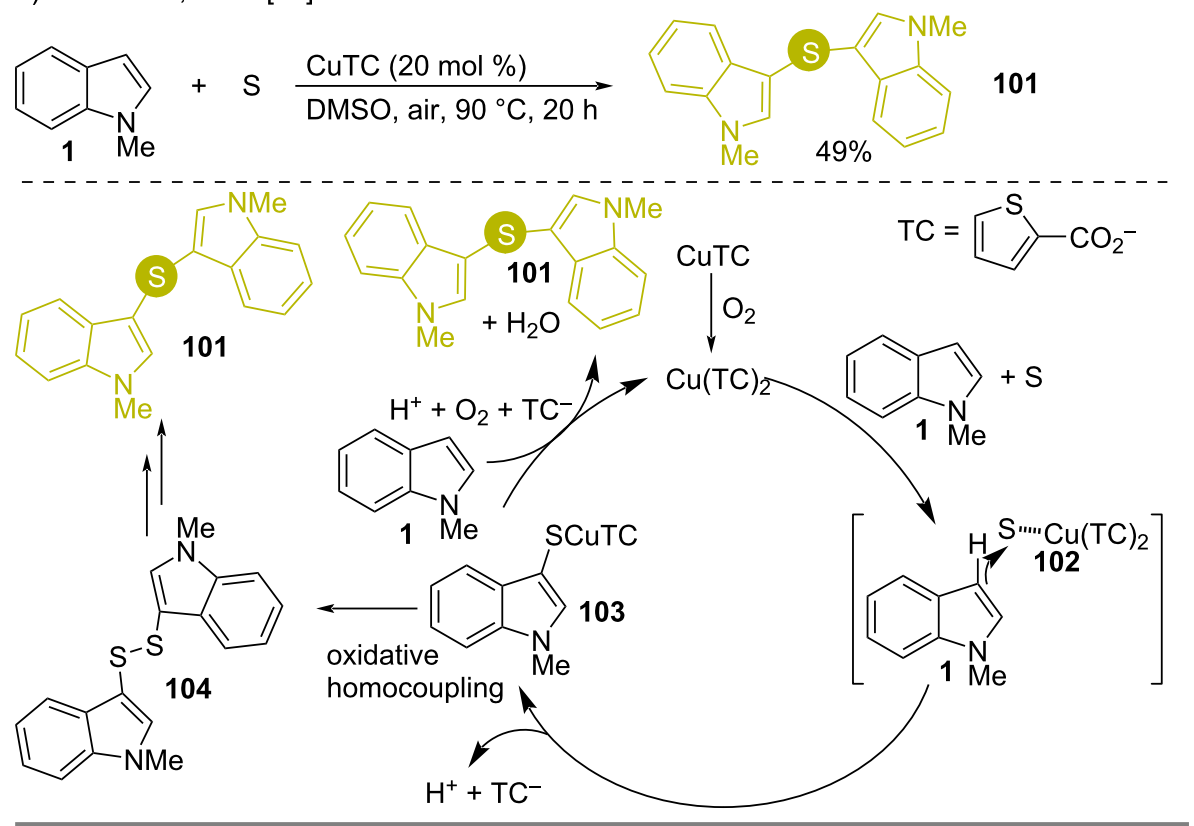

b) Yang, 2016 [83]

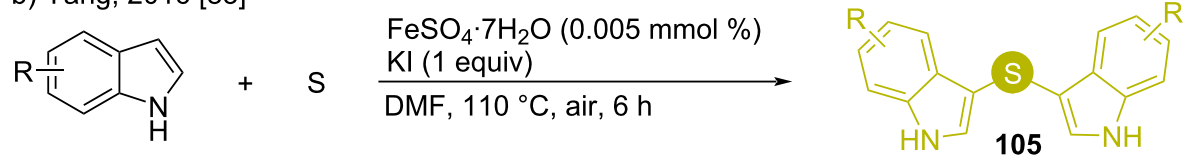

$\mathrm{R}=\mathrm{H}, 95 \% ; 5-\mathrm{CH}_{3}, 94 \% ; 7-\mathrm{CH}_{3}, 92 \% ; 5-\mathrm{Br}, 78 \% ; 5-\mathrm{CN}, 82 \%$; $5-\mathrm{CHO}, 74 \% ; 5-\mathrm{NO}_{2}, 53 \% ; 6-\mathrm{Cl}, 69 \% ; 6-\mathrm{COOCH}_{3}, 65 \%$

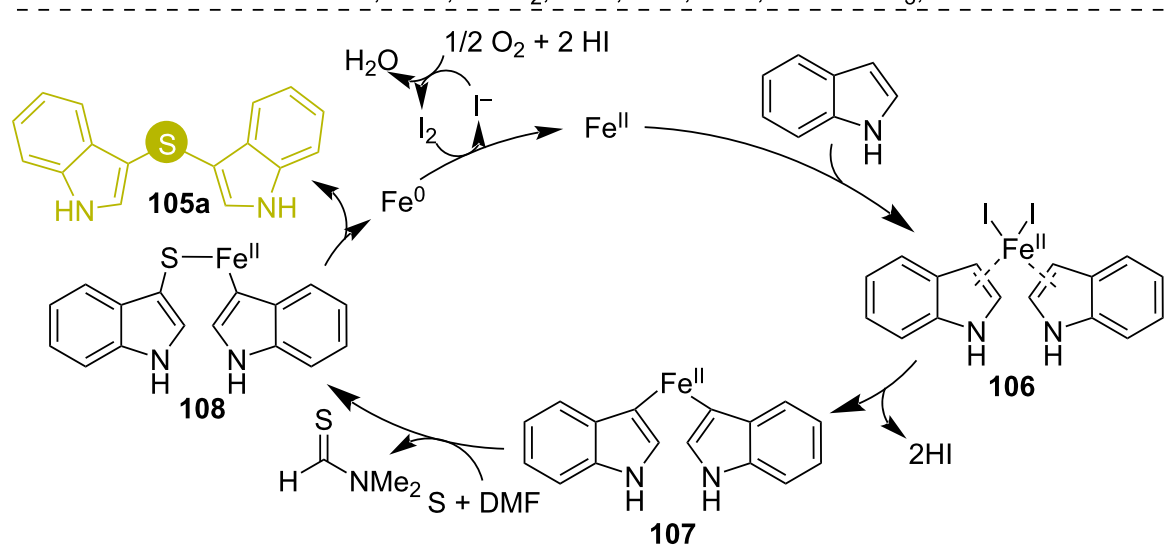

Scheme 15: Oxidative synthesis of bis(indol-3-yl)sulfides using indoles and elemental sulfur.

$N$-protected indoles 1 or $\mathbf{6 1}$ [85]. The products 116 were formed within a few seconds in the presence of a moderate base at high temperature (Scheme 16b), tolerating groups having both electron-donating and withdrawing nature on $\mathbf{1}$. Here the base assisted the condensation of 2-(fluorosulfonyl)difluoroacetic acid (115) with 1 followed by decarboxylation to give difluorocarbene and sulfinate 119, that combine to produce sulfanol 121, which in the presence of acid and reaction with another molecule of indole affords $\mathbf{1 0 5}$.
In 2018, Procter used a similar strategy to that reported by Hamashima for the synthesis of similar molecules 125 with good to moderate yields using electron-donating groups at the indole ring. The yields decreased with indoles having electronwithdrawing groups (Scheme 16c) [86]. Here diallyl sulfoxide (123) was used with TFAA to obtain diallyl intermediate 127. The latter undergoes a [3,3]-sigmatropic reaction to afford allyl (2-allylindol-3-yl)sulfide 128, which is oxidized by $m$-CPBA to sulfine 124. Repetition of the steps along with indole addition 
a) Hamashima, 2013 [84]<smiles>CS(=O)c1c[nH]c2ccccc12</smiles>

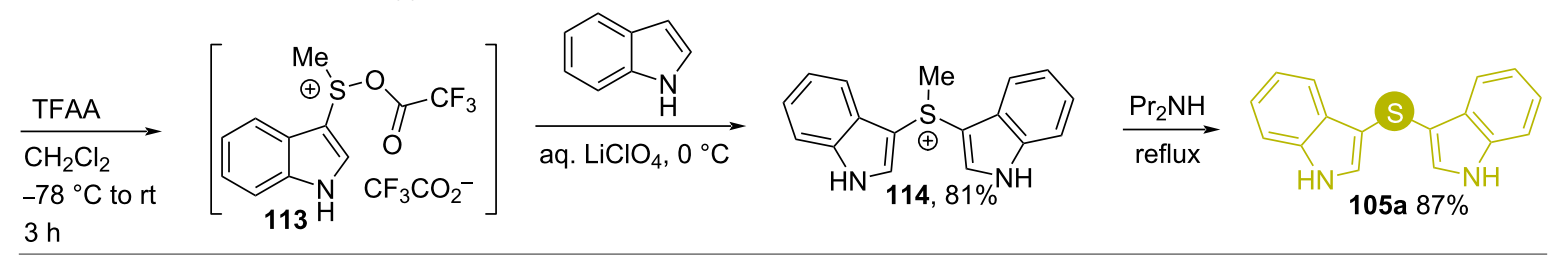

b) Li, 2018 [85]

or 61

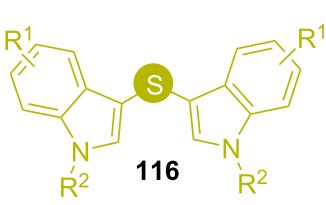

$\mathrm{R}^{1}=\mathrm{H}, \mathrm{R}^{2}=\mathrm{Me}, 79 \%$

$\mathrm{R}^{1}=5-\mathrm{OMe}, \mathrm{R}^{2}=\mathrm{Me}, 75 \%$;

$\mathrm{R}^{1}=6-\mathrm{F}, \mathrm{R}^{2}=\mathrm{Me}, 68 \%$;

$\mathrm{R}^{1}=\mathrm{H}, \mathrm{R}^{2}=6-\mathrm{CO}_{2} \mathrm{Me}, 48 \%$;

$\mathrm{R}^{1}=5-\mathrm{CN}, \mathrm{R}^{2}=\mathrm{Me}, 60 \%$;

$\mathrm{R}^{1}=5-\mathrm{CHO}, \mathrm{R}^{2}=\mathrm{Me}, 58 \%$

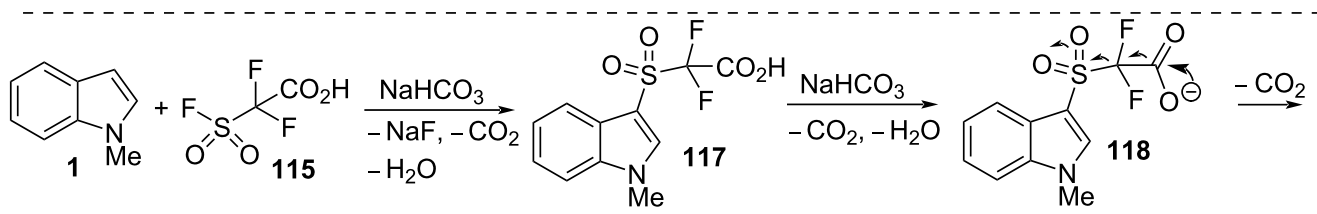

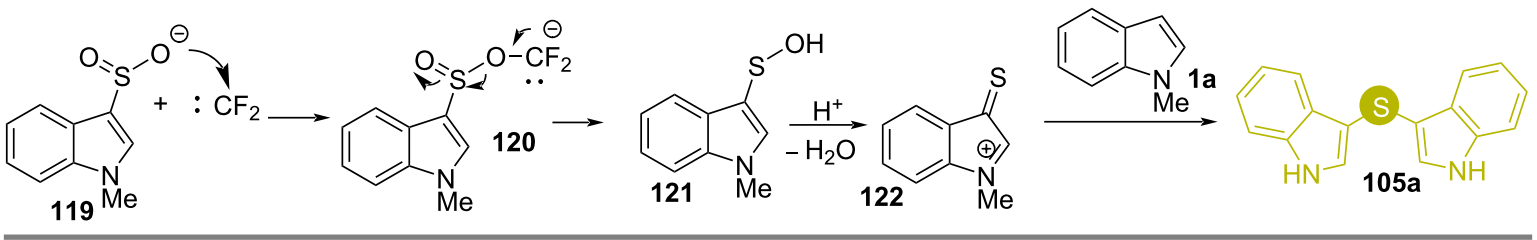

c) Procter, 2018 [86]

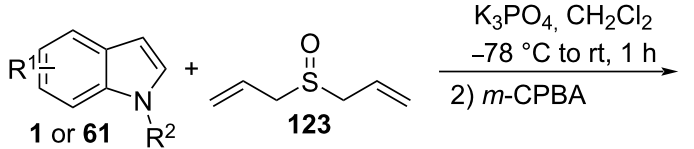

1) TFAA (1.1 equiv) $\mathrm{K}_{3} \mathrm{PO}_{4}, \mathrm{CH}_{2} \mathrm{Cl}_{2}$ 1 or 61 R 123<smiles>[R2]n1c(CC=C)c(S(=O)CC=C)c2cc[R1]cc21</smiles>

124

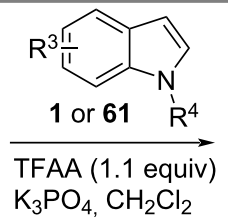

$-78^{\circ} \mathrm{C}$ to $\mathrm{rt}, 1 \mathrm{~h}$

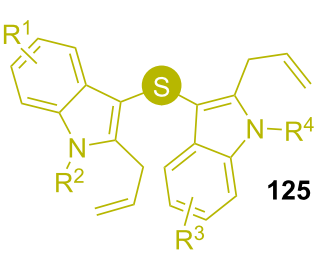

$R^{1}=R^{2}=R^{3}=R^{4}=H, 64 \% ; R^{1}=R^{3}=R^{4}=H, R^{2}=M e, 67 \% ; R^{1}=R^{4}=H, R^{2}=M e, R^{3}=B r, 51 \%$<smiles>C=CC[AsH2]S(=O)CC=C</smiles>
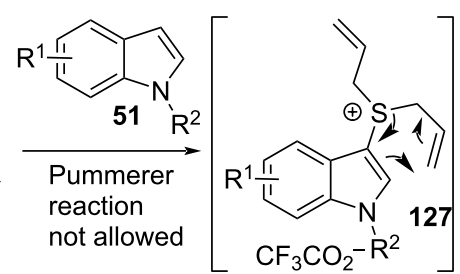

[3,3]-sigmatropic

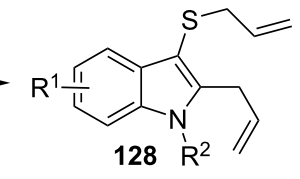<smiles></smiles>

1) TFAA
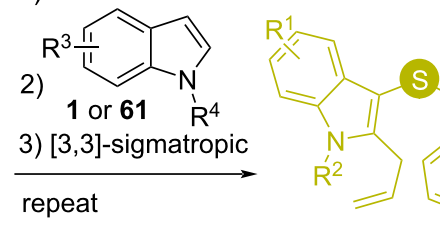

125 
led to the desired products. Here the absence of a $\beta$-hydrogen in the diallylsulfoxide (123) did not allow any Pummerer rearrangement $[88,89]$.

\section{Selenides}

In 1997, Showalter synthesized bis(indol-2-yl)selanes (or selenides) $\mathbf{1 3 0}$ having potential tyrosine kinase inhibitor activities $[90,91]$. The synthesis was achieved by reacting diselenium dichloride with $(R)$-tryptophan amide 129 (Scheme 17a) [92] Bis(indol-2-yl)selane $\mathbf{1 3 0}$ was found as a byproduct having very low such bioactivity. The polyselanes formed were separated by treating them with $\mathrm{NaBH}_{4}$, which did not affect the monoselane $\mathbf{1 3 0}$.

On the other hand, selenopyrans structurally resemble indolocarbazoles, which possess AhR affinity [93]. Janosik presented a synthesis of such selenopyrans $\mathbf{1 3 2}$ via the bis(indol-2yl)selanes 131 [73]. Treating these compounds with orthoformate esters in the presence of the Brønsted acid $\mathrm{MeSO}_{3} \mathrm{H}$ led to the target selenopyrans (Scheme 17b). The methylated analogs of $\mathbf{1 3 2}$ displayed high efficiency for activating AhR.

Bis(indol-3-yl)selanes possess antioxidant properties. Pioneered by Wilshire [94], their syntheses were studied by Abele [95], Naidu [96], Yang [83], Thurow [97], and Talukdar [98]. The work of Abele in 2004 involved refluxing $\mathrm{SeO}_{2}$ with $N$-unprotected indole in benzene which resulted in low yields of the products 134 (Scheme 18a) [44]. Using different $N$-protected substituted indoles 135, Naidu observed improved yields of 136 when catalytic oxidant $I_{2}$ was added in 1,4-dioxane as solvent (Scheme 18b) [96]. Using aerial oxygen as the oxidant, Yang used $\mathrm{Se}^{0}$ in the presence of stoichiometric KI and catalytic amounts of $\mathrm{Fe}^{\mathrm{II}}$ for the synthesis of similar bis(indol-3yl)selanes (Scheme 18c) [83].

In 2018 Thurow reported a method using stoichiometric $\mathrm{SeO}_{2}$ along with sub-stoichiometric PhSSPh (138) to obtain a mixture of the desired diindol-3-ylselane (137a) along with monoand di(phenylthio)-substituted indoles 139 and 140 (Scheme 18d) [97]. Catalytic iodine was used to oxidize $\mathrm{PhSSPh}(\mathbf{1 3 8})$ to PhSI (141), to which indole adds to give (phenylthio)indole 139 along with $\mathrm{HI}$. HI reduces $\mathrm{SeO}_{2}$ to $\mathrm{Se}$. Se interacts with two molecules of indole in the presence of air to give the desired product $137 \mathbf{a}$. In a parallel pathway the product decomposes to selenone 144, 3-(phenylthio)indole (139) and regenerates $\mathrm{Se}$.

In a recent effort by Talukdar, the cheap and non-anhydrous solvent ethanol was used to prepare the desired bis(indol-3yl)selanes 136 in moderate yields [98]. Following the assumption (formation of triselenide 145) made by Wilshire [94] together with the detection of the oxidized products isatins in the reaction mixture, a disproportionation mechanism of $\mathrm{SeO}_{2}$ can be drawn giving bis(indol-3-yl)triselenide 145 and $\mathrm{Se}^{\mathrm{VI}}$ (Scheme 18e). The triselenide 145 converts into bis(indol-3yl)selane 146 with liberation of $\mathrm{Se}^{0} . \mathrm{Se}^{\mathrm{VI}}$ can generate $\mathrm{Se}^{\mathrm{II}}$ or

a) Showalter, 1997 [92]<smiles>[R]N[C@@H](Cc1c[nH]c2ccccc12)C(=O)NCc1ccccc1</smiles>

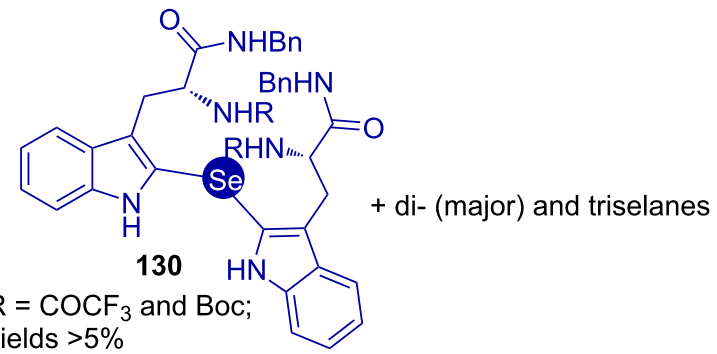

b) Janosik, 2009 [73]<smiles>[X]c1ccc2[nH]ccc2c1</smiles>
1. $n$-BuLi, THF, $-78^{\circ} \mathrm{C}, \mathrm{CO}_{2}$ 2. $t$-BuLi, $\left(\mathrm{PhSO}_{2}\right)_{2} \mathrm{Se}, \mathrm{rt}, 16 \mathrm{~h}$<smiles>[X]c1ccc2[nH]c([Se][Se]c3cc4cc([X])ccc4[nH]3)cc2c1</smiles>
$\mathrm{X}=\mathrm{OMe}, 69 \%$

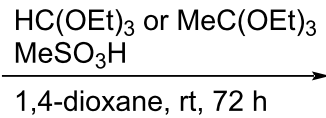

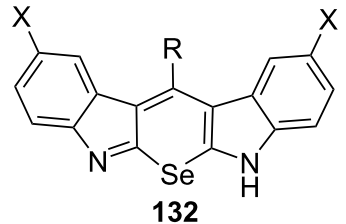

$X=O M e, R=\operatorname{Me}(45 \%)$ 
a) Abele, 2004 [95]

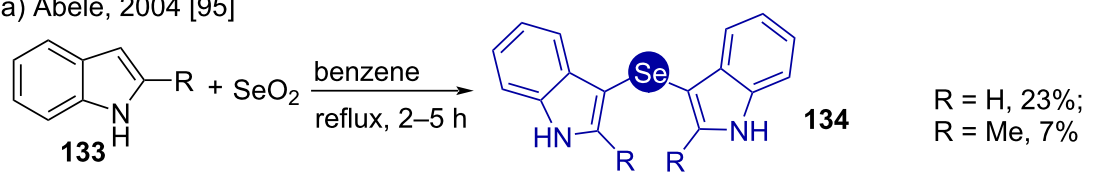

b) Naidu, 2015 [96]<smiles>[R16]c1cc2cc[R1]cc2n1[R16]</smiles><smiles>[R][R]1c([R])c([Se]c2c([R])n([R1])c3cc[R]:[R]c23)c2ccccc12</smiles>

$\mathrm{R}^{1}=\mathrm{R}^{2}=\mathrm{R}^{3}=\mathrm{H}, 75 \%$

$R^{1}=R^{2}=H, R^{3}=5-B r, 72 \%$

$\mathrm{R}^{1}=\mathrm{R}^{2}=\mathrm{H}, \mathrm{R}^{3}=6-\mathrm{Br}, 80 \%$

$R^{1}=M e, R^{2}=R^{3}=H, 78 \%$

$R^{1}=M e, R^{2}=H, R^{3}=5-B r, 70 \%$

$R^{1}=R^{3}=H, R^{2}=M e, 74 \%$

c) Yang, 2016 [83] (see Scheme $16 \mathrm{~b}$ for mechanism)
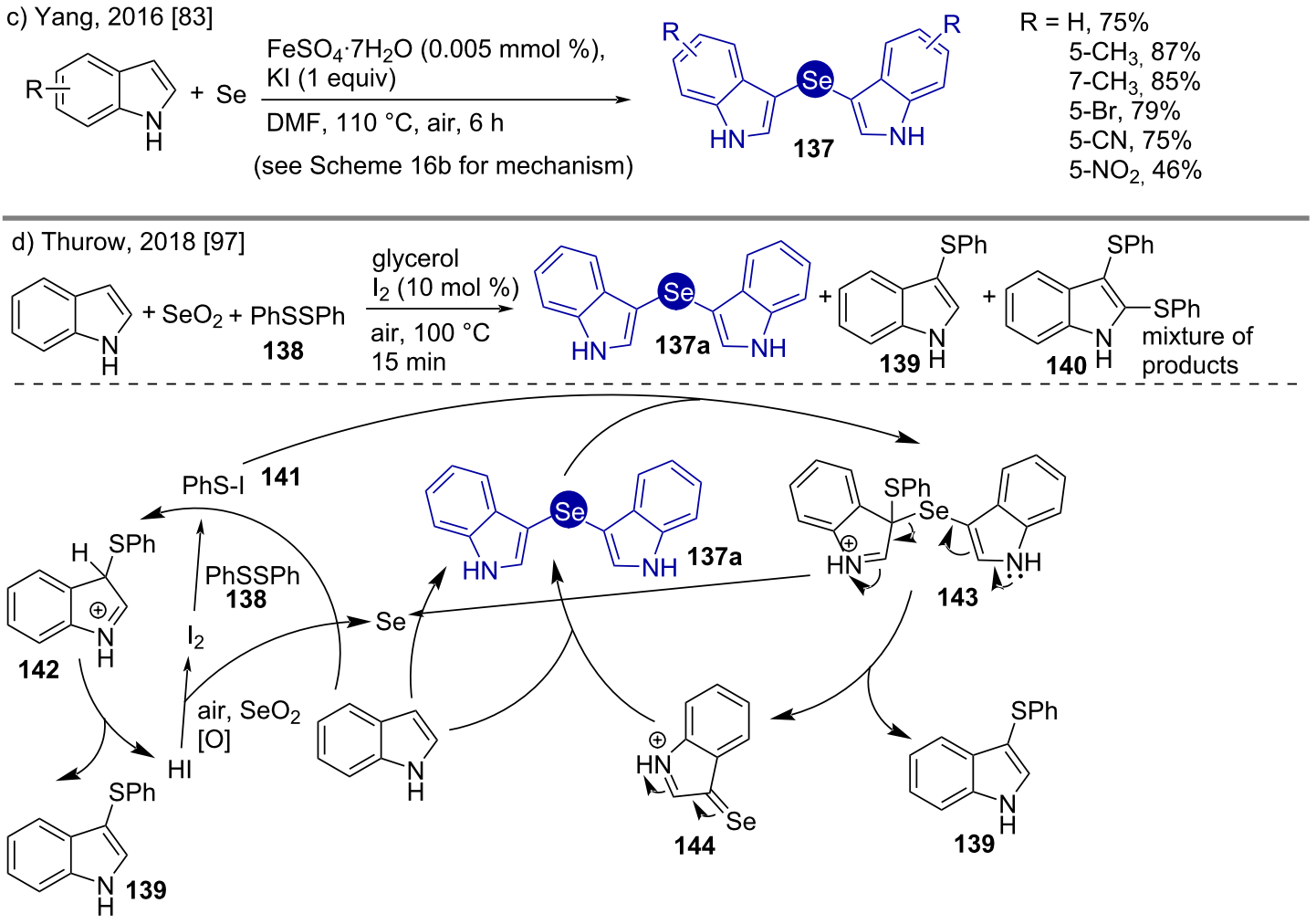

e) Talukdar, 2019 [98]

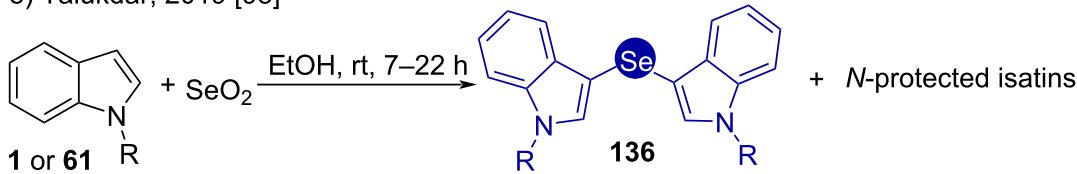

$\mathrm{R}=\mathrm{H}, 62 \%, \mathrm{R}=\mathrm{Me}, 45 \%, \mathrm{R}=\mathrm{Bn}, 50 \%, \mathrm{R}=\mathrm{iPr}, 71 \%, \mathrm{R}=$ allyl, $54 \%, \mathrm{R}=$ cyanomethyl, $79 \%$ $\mathrm{R}=3$-chloropropyl, $48 \%, \mathrm{R}=$ ethyl-3-propanoyl, $70 \%, \mathrm{R}=\mathrm{Ph}, 65 \%, \mathrm{R}=$ propargyl, $18 \%$

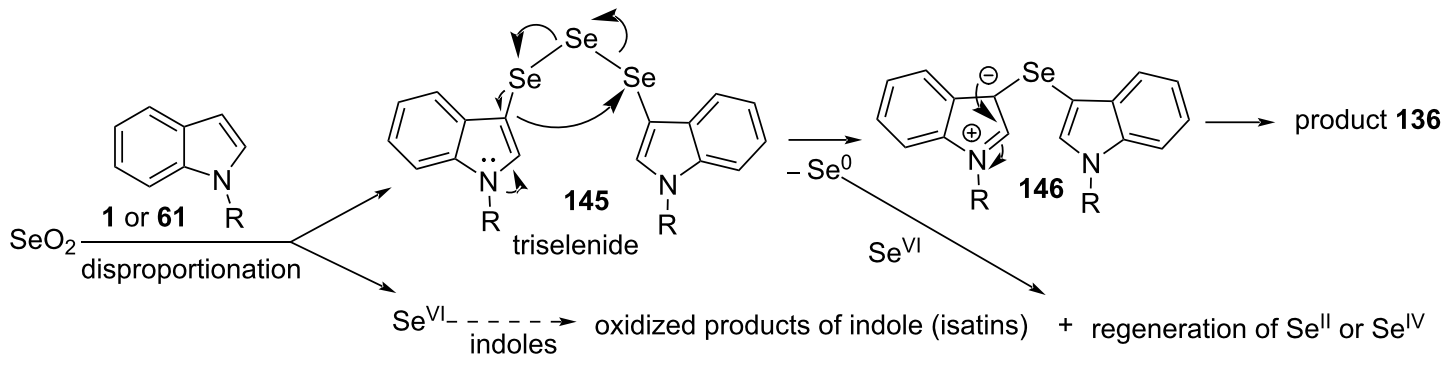


$\mathrm{Se}^{\mathrm{IV}}$ by either oxidizing indoles to isatins, or by a comproportionation reaction with $\mathrm{Se}^{0}$ to give $\mathbf{1 3 6}$.

\section{Tellurides}

Engman claimed a synthesis of the titular compounds 147 and 148 in the year 1994 by reacting the $\mathrm{C} 2$ anion 149 of the $N$-sulfonyl-protected indole 10 with metallic Te in four steps including desulfonylation (Scheme 19) [99]. The treatment with base followed by the addition of elemental tellurium to N-protected indole 10 generates lithium telluride $\mathbf{1 5 0}$. Telluride $\mathbf{1 5 0}$ is then oxidized to ditelluride $\mathbf{1 5 1}$ by treatment with ferrocyanide. A $\mathrm{Cu}$ powder-mediated reduction gives the $\mathrm{N}$-protected bis(indol2-yl)tellane 147. The final desulfonated product 148 is a potent thiol peroxidase reducing agent [100].

\section{The benzenoid C4 and C7 linkages}

The syntheses of bisindolyl non-metallides connected through benzenoid rings of the indoles are less studied compared to the same through their pyrrole counterpart. The corresponding compounds are investigated for boron, nitrogen, oxygen, sulfur, and selenium as the central connecting atom.

\section{Boranes}

The indole alkaloid dragmacidin D is a marine secondary metabolite which was recently found active against Parkinson's and Alzheimer's diseases [101-103]. In 2002, Jiang, while studying its synthesis, found the tris(indolyl)borane 154 instead of the desired chiral indole alcohol $\mathbf{1 5 5}$ while reacting the $N$-silylated 4-bromoindole 152 with $n$-BuLi in a failed regioselective ring opening attempt of chiral oxirane 153 in the presence of $\mathrm{BF}_{3} \cdot \mathrm{Et}_{2} \mathrm{O}$ (Scheme 20) [104]. The synthetic route to the desired product was smoothly brought to its course by employing $\mathrm{CuCN}$ in the medium.

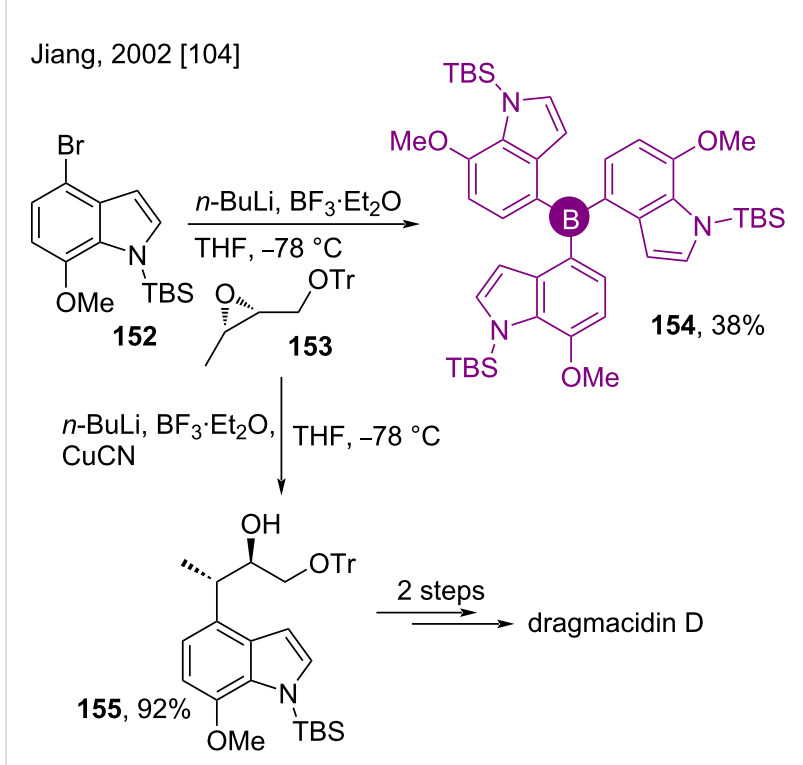

Scheme 20: Synthesis of tris(indolyl)borane 154.

\section{Engman, 1994 [99]}<smiles>c1ccc2[nH]ccc2c1</smiles>

10 $\mathrm{SO}_{2} \mathrm{Ph}$
1. $t$-BuLi, THF, $-78{ }^{\circ} \mathrm{C}, 45 \mathrm{~min}$ $\mathrm{Te}^{0}$ powder, rt, $2 \mathrm{~h}$ 2. $\mathrm{K}_{3} \mathrm{Fe}(\mathrm{CN})_{6}$

3. $\mathrm{Cu}^{0}$ powder, 1,4-dioxane, reflux, $1 \mathrm{~h}$

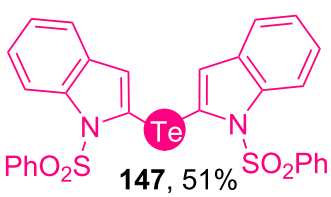

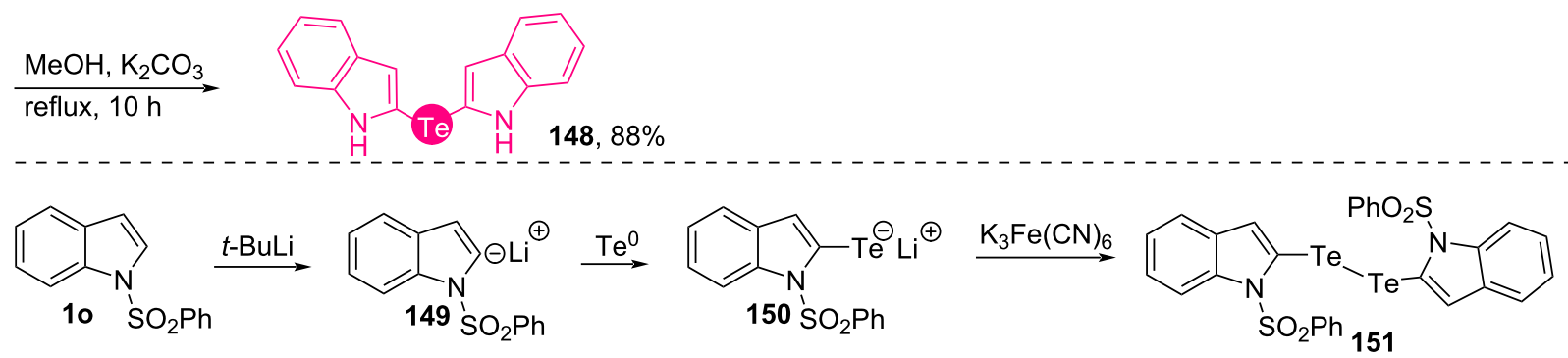
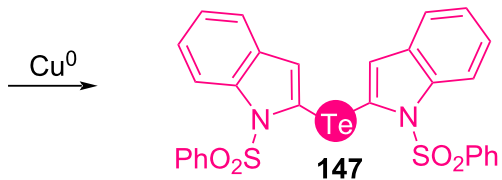


\section{Amines}

The enzymes indoleamine 2,3-dioxygenase 1 (IDO1) and tryptophan 2,3-dioxygenase (TDO) are responsible for tryptophan metabolism in the human body. Thus, the inhibition of these enzymes may help in tumor immunotherapy [105-107]. Xu recently found indole-2-carboxylic acid derivatives as IDO1/ TDO dual inhibitors. In their effort to synthesize the following bis(indol-4-yl)amine derivatives via a Buchwald amination led to the 4-amino-substituted compounds $\mathbf{1 5 8}$ or acids $\mathbf{1 5 9}$ after basic hydrolysis (Scheme 21) [108]. Compound 159c had the maximum potency against IDO1 and TDO with $\mathrm{IC}_{50}$ values of $2.72 \mathrm{mM}$ and $3.48 \mathrm{mM}$, respectively compared to $159 \mathrm{a}$ and 159b, which is 15 and 28.5 times higher than that of hit compound 160.

As discussed earlier, bis(indolyl)amines possess electroluminescent properties [41,109]. In 2009, Yagi and co-workers synthesized a large library of bis(indol-5-yl)amines $\mathbf{1 6 3}$ for studying their efficiency in organic electroluminescent devices, where 5-bromoindoles and 5-aminoindoles were taken as partners in a Buchwald coupling (Scheme 22a) [44]. On the other hand, in 2015, Organ's group performed a phosphine-ligand free Buchwald amination of 5-chloroindole (164) with amine 165 to give the desired product $\mathbf{1 6 7}$, where the use of the Pd-PEPPSI-
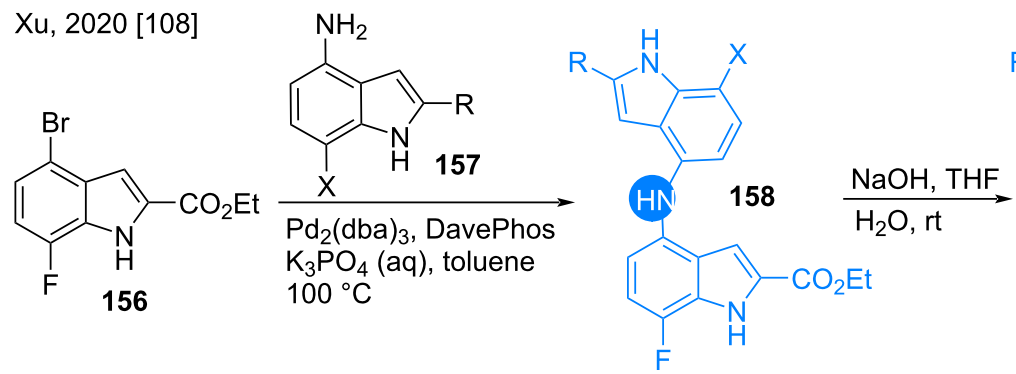

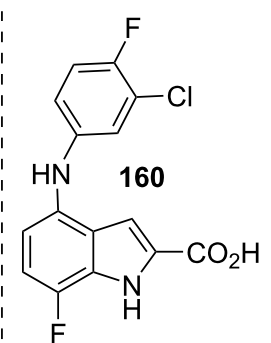

159a: $X=H, R=H, 92 \%$;

159b: $X=F, R=H, 96 \%$;

159c: $X=F, R=\mathrm{CO}_{2} \mathrm{H}, 92 \%$

Scheme 21: Synthesis of bis(indol-4-yl)amines 159

a) Yagi, 2009 [44]<smiles>[R]c1c([NH2+])[nH]c2ccc(Br)cc12</smiles>

$161 \mathrm{R}^{2}$<smiles>[R]c1[nH]c2ccc(N)cc2c1[R]</smiles>

$162 \mathrm{R}^{2}$
$t$-BuONa, $t-\mathrm{Bu}_{3} \mathrm{P}$ $\mathrm{Pd}(\mathrm{OAc})_{2}$ xylene, $2 \mathrm{~h}, 100{ }^{\circ} \mathrm{C}$

$\mathrm{R}^{1}=\mathrm{H}, \mathrm{Me}, \mathrm{OMe}, \mathrm{F}, \mathrm{Ph},-\left(\mathrm{CH}_{2}\right)_{4^{-}}, \mathrm{CF}_{3}, \mathrm{SPh}$;

$\mathrm{R}^{2}=\mathrm{Me}, \mathrm{Ph}, 1$-naphth, 2-naphth, 9-anthra, 9-phen, 2-Py, 4-Py, 2-thienyl, 4-biph, 4- $\mathrm{CNC}_{6} \mathrm{H}_{4}, 4-\mathrm{MeC}_{6} \mathrm{H}_{4}$<smiles></smiles>

b) Organ, 2015 [110]<smiles>NCCc1ccccc1</smiles>

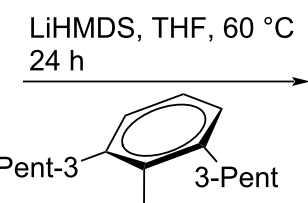

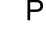<smiles>[18OH]c1ccccc1NCCc1ccccc1</smiles><smiles>C(=NCCc1ccccc1)c1ccc2[nH]ccc2c1</smiles>

$168,3 \%$

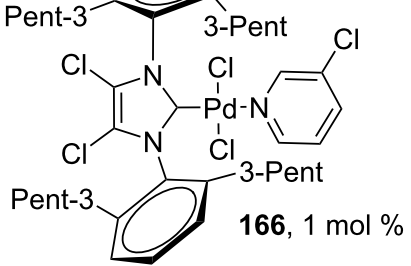<smiles>c1ccc2[nH]ccc2c1</smiles> 
IPent ${ }^{\mathrm{Cl}}$ precatalyst 166 in presence of the strong base led to the formation of the over-aminated product $\mathbf{1 6 8}$ (Scheme 22b) [110].

Alzheimer's disease is caused by the $\beta$-amyloid-42 aggregation in brain tissue [111,112]. In 2017, Sreenivasachary synthesized a library of 6,5'- and 6,6'-bis(indolyl)amines and other similar 7-azaindole derivatives as potent anti-Alzheimer agents (171, 172) by a Buchwald coupling of the corresponding C 3 -substituted amines 170 and indole 5/6-bromides 169 (Scheme 23) [113]. Cyano, 4-piperidinyl and $N$-methylpiperidinyl substitutions at the indole and 7-azaindoles were necessary to improve the brain penetration ability of the products.
Up to $>80 \%$ inhibition of the amyloid- $\beta$ peptide aggregates were achieved with these compounds, with the highest activity found for the 4- $\mathrm{N}$-methylpiperidyl derivative.

\section{Ethers}

The synthesis of the bis(indol-6-yl) ether 175 was performed by Chai in 2017. Their protocol used a $\mathrm{Cu}(\mathrm{OAc})_{2}$-mediated coupling of $N$-silylated 6-hydroxyindole 174 with the corresponding boronic acid $\mathbf{1 7 3}$ (Scheme 24) [114]. For further synthetic transformations of 175, $\mathrm{N}$-protection with bromo esters 176 followed by hydrolysis towards acids $\mathbf{1 7 7} \mathbf{a}$ and $\mathbf{1 7 7 b}$ were performed. The products $\mathbf{1 7 7} \mathbf{a}$ and $\mathbf{1 7 7} \mathbf{b}$ are potent anti-HIV agents.

Sreenivasachary, 2017 [113]<smiles>[R]c1cn([R2])c2c1c(N)c[Y]2([H])[H]</smiles>

i) $\mathrm{Pd}(\mathrm{OAc})_{2}$ XPhos, $t$-BuONa dioxane, $110^{\circ} \mathrm{C}, 2 \mathrm{~h}$

$\mathrm{Pd}(\mathrm{OAc})_{2}$, XPhos, $\mathrm{K}_{2} \mathrm{CO}_{3}$ $t-\mathrm{BuOH}, 110^{\circ} \mathrm{C}, 3 \mathrm{~h}$

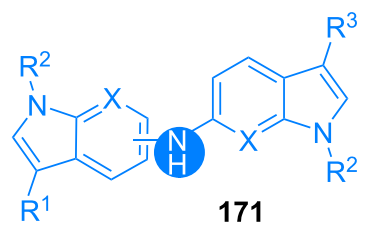

(ii) $1 \mathrm{M} \mathrm{TBAF/THF}, \mathrm{CH}_{3} \mathrm{CN}$ $\mathrm{rt}, 1 \mathrm{~h}$

(iii) $1 \mathrm{M} \mathrm{HCl} / \mathrm{H}_{2} \mathrm{O}, \mathrm{rt}, 16 \mathrm{~h}$

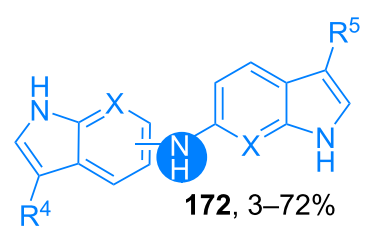

$\mathrm{R}^{1}=\mathrm{CN}$;

$\mathrm{R}^{2}=\mathrm{H}$ or TIPS;

$\mathrm{R}^{3}=4-\mathrm{NBoc}$-piperidinyl, 4-NMe-piperidyl;

$\mathrm{R}^{4}=\mathrm{CN}$;

$\mathrm{R}^{5}=4$-piperidinyl, 4-NMe-piperidyl;

$\mathrm{X}=\mathrm{CH}, \mathrm{N}$

Chai, 2017 [114]

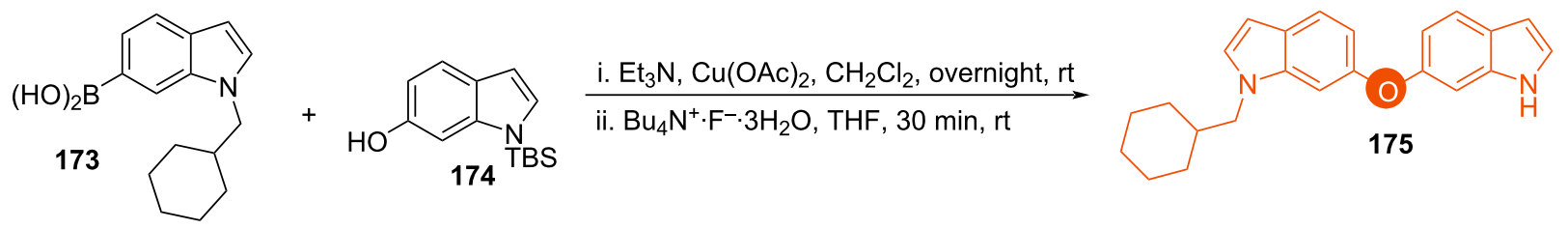

i. $\mathrm{NaH}, \mathrm{DMF}, \mathrm{Br} \smile \mathrm{Ar}_{-} \begin{gathered}176 \\ \mathrm{CO}_{2} \mathrm{Me}\end{gathered}$

ii. $\mathrm{NaOH}, \mathrm{THF} / \mathrm{MeOH}$ then $\mathrm{H}_{3} \mathrm{O}^{+}$<smiles>O=C(O)[Al]Cn1ccc2ccc(Oc3ccc4ccn(CC5CCCCC5)c4c3)cc21</smiles>
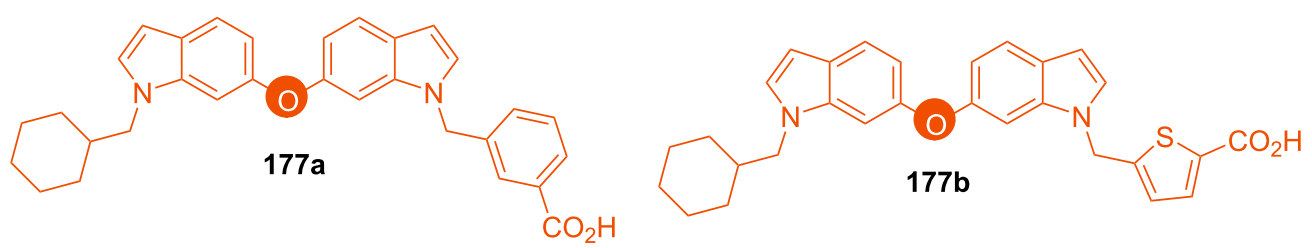
Although the synthesis of $7,7^{\prime}$-bis-indolyl ether was known prior to Chai's report [114]. In 1989, Black found the 7,7'dimerised product $\mathbf{1 7 9}$ of the indole derivative $\mathbf{1 7 8}$ as a hindered biphenyl analog via its prompt oxidation in the presence of quinones. The bis(indol-7-yl) ether $\mathbf{1 8 0}$ was found in $10 \%$ yield when chloranil was used as the oxidant (Scheme 25) [115]. The high electrophilicity of $\mathbf{1 7 8}$ at the $\mathrm{C} 7$ position resulted in this product formation. The reaction proceeds through the radical intermediate $\mathbf{1 8 1}$.

\section{Sulfides}

Reddy synthesized the di(indol-5-yl)sulfide (183) via a cascade strategy with 5-iodoindole (182) in the presence of thiourea and a recyclable $\mathrm{CuO}$ nanoparticle catalyst (Scheme 26) [116]. This heterogeneous catalysis strategy bypasses the use of unpleasant aryl thiols, which are generally coupled with other aryl halides in the presence of transition-metal catalysts for obtaining diaryl sulfides [117].

\section{Selenides}

Along with the oxygen insertion, Black et al. also performed the oxidative selenium insertion into the C-7 position of highly electrophilic 2-methylindole derivative 184. The dual role of selenium dioxide consists of activation of the $\mathrm{C}-7$ position giving the dimerized $7,7^{\prime}$-bis(indolyl) products $\mathbf{1 8 5}$ with the 2-methyl group transformed to the aldehyde in the same step (Scheme 27) [118,119]. The less electronically activated $N$-acyl substrate gave a slightly better yield. Selenation occurs at C-3 instead of C-7 for the C-3 unsubstituted substrates.

\section{Conclusion}

This review summarizes the various (un)catalytic synthetic techniques of the symmetric and unsymmetric bis/tris(indolyl)containing non-metallides consisting of multiple indole molecules covalently connected via C2, C3 (pyrrole ring) and C4-C7 (benzenoid ring) by different central atoms. Like the bis(indolyl)methanes (anticancer substances), these products are<smiles>COc1cc(OC)c2c(-c3ccccc3)c(-c3ccccc3)[nH]c2c1</smiles>
178<smiles>COc1cc(OC)c2c(-c3ccccc3)c(-c3ccccc3)[nH]c2c1-c1c(OC)cc(OC)c2c(-c3ccccc3)c(-c3ccccc3)[nH]c12</smiles>

$179,70 \%$<smiles>COc1cc(OC)c2c(-c3ccccc3)c(-c3ccccc3)[nH]c2c1OC(=O)c1c(OC)cc(OC)c2c(-c3ccccc3)c(-c3ccccc3)[nH]c12</smiles>

$180,10 \%$<smiles>COc1cc(OC)c2c(-c3ccccc3)c(-c3ccccc3)[nH]c2c1</smiles>

Scheme 25: Synthesis of bis(indol-7-yl) ether.

Reddy, 2011 [116]
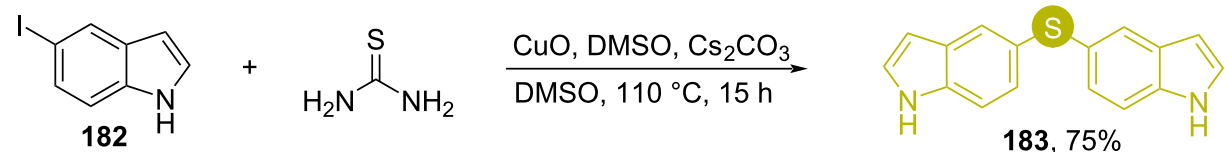

Scheme 26: Synthesis of di(indol-5-yl)sulfide (183).

Black, 2005 [118]<smiles>COc1cc(OC)c2c(-c3ccccc3)c(C)[nH]c2c1</smiles>

\section{$\mathrm{SeO}_{2}$, 1,4-dioxane} reflux, $9 \mathrm{~h}$

184<smiles></smiles>

$\mathrm{R}=\mathrm{H}, 31 \%$

$\mathrm{R}=\mathrm{COMe}, 35 \%$ 
important potential pharmaceutically active ingredients as well. As a result, they have gathered much attention in the current decade as suggested by the number of contemporary publications associated. The described schemes involve both simple and challenging strategies depending on the central tethering atom involved. As time progresses, research on the synthesis and application of this class of molecules will be more broadened.

\section{ORCID ${ }^{\circledR}$ iDs}

Ranadeep Talukdar - https://orcid.org/0000-0001-8137-0764

\section{References}

1. Rahman, A.; Basha, A. Indole Alkaloids, 1st ed.; Frontiers in Natural Product Research Series, Vol. 2; Taylor \& Francis, 1998.

2. Higuchi, K.; Kawasaki, T. Nat. Prod. Rep. 2007, 24, 843-868. doi:10.1039/b516351j

3. Ruiz-Sanchis, P.; Savina, S. A.; Albericio, F.; Álvarez, M. Chem. - Eur. J. 2011, 17, 1388-1408. doi:10.1002/chem.201001451

4. Kaushik, N. K.; Kaushik, N.; Attri, P.; Kumar, N.; Kim, C. H.; Verma, A. K.; Choi, E. H. Molecules 2013, 18, 6620-6662. doi:10.3390/molecules18066620

5. Yanagihara, M.; Sasaki-Takahashi, N.; Sugahara, T.; Yamamoto, S.; Shinomi, M.; Yamashita, I.; Hayashida, M.; Yamanoha, B.; Numata, A.; Yamori, T.; Andoh, T. Cancer Sci. 2005, 96, 816-824. doi:10.1111/j.1349-7006.2005.00117.x

6. Barden, T. C. Indoles: Industrial, Agricultural and Over-the-Counter Uses. In Heterocyclic Scaffolds II; Gribble, G., Ed.; Topics in Heterocyclic Chemistry, Vol. 26; Springer: Berlin, Heidelberg, 2011; pp 31-46. doi:10.1007/7081_2010_48

7. Zhao, S.; Andrade, R. B. J. Am. Chem. Soc. 2013, 135, 13334-13337. doi:10.1021/ja408114u

8. Teng, M.; Zi, W.; Ma, D. Angew. Chem., Int. Ed. 2014, 53, 1814-1817. doi:10.1002/anie.201310928

9. Cacchi, S.; Fabrizi, G. Chem. Rev. 2011, 111, PR215-PR283. doi:10.1021/cr100403z

10. Sundberg, R. J. The Chemistry of Indoles; Academic Press: New York, NY, USA, 1970

11. Lakhdar, S.; Westermaier, M.; Terrier, F.; Goumont, R.; Boubaker, T.; Ofial, A. R.; Mayr, H. J. Org. Chem. 2006, 71, 9088-9095. doi:10.1021/jo0614339

12. Cooper, M. M.; Hignett, G. J.; Newton, R. F.; Joule, J. A.; Harris, M.; Hinchley, J. D. J. Chem. Soc., Chem. Commun. 1977, 432-434. doi:10.1039/c39770000432

13. Kishbaugh, T. L. S. Reactions of Indole with Nucleophiles. In Heterocyclic Scaffolds II; Gribble, G., Ed.; Topics in Heterocyclic Chemistry, Vol. 26; Springer: Berlin, Heidelberg, 2010; pp 117-140. doi:10.1007/7081_2010_35

14. Talukdar, R.; Tiwari, D. P.; Saha, A.; Ghorai, M. K. Org. Lett. 2014, 16, 3954-3957. doi:10.1021/ol501763n

15. Talukdar, R. Org. Biomol. Chem. 2020, 18, 8876-8880. doi:10.1039/d0ob01977a

16. Wu, H.; Liu, B.; Yang, K.; Winston-McPherson, G. N.; Leisten, E. D.; Vezina, C. M.; Ricke, W. A.; Peterson, R. E.; Tang, W. Bioorg. Med. Chem. Lett. 2020, 30, 126959. doi:10.1016/j.bmcl.2020.126959
17. Winston-McPherson, G. N.; Xie, H.; Yang, K.; Li, X.; Shu, D.; Tang, W. Bioorg. Med. Chem. Lett. 2019, 29, 2345-2348. doi:10.1016/j.bmcl.2019.06.014

18. Lucarini, S.; Antonietti, F.; Tontini, A.; Mestichelli, P.; Magnani, M.; Duranti, A. Tetrahedron Lett. 2011, 52, 2812-2814. doi:10.1016/j.tetlet.2011.03.117

19. Noguchi-Yachide, T.; Tetsuhashi, M.; Aoyama, H.; Hashimoto, Y. Chem. Pharm. Bull. 2009, 57, 536-540. doi:10.1248/cpb.57.536

20. Nazari, P.; Noroozi, M.; Papan, A. M.; Ghanavati, S. P. M. Int. J. Mod. Pharm. Res. 2019, 3 (6), 11-17.

21. Gao, N.; Cheng, S.; Budhraja, A.; Liu, E.-H.; Chen, J.; Chen, D.; Yang, Z.; Luo, J.; Shi, X.; Zhang, Z. PLoS One 2012, 7, e31783. doi:10.1371/journal.pone.0031783

22. Thomson, C. A.; Ho, E.; Strom, M. B. Nutr. Rev. 2016, 74, 432-443. doi:10.1093/nutrit/nuw010

23. Shiri, M.; Zolfigol, M. A.; Kruger, H. G.; Tanbakouchian, Z. Chem. Rev. 2010, 110, 2250-2293. doi:10.1021/cr900195a

24. Reck, C. E.; Bretschneider-Hurley, A.; Heeg, M. J.; Winter, C. H. Organometallics 1998, 17, 2906-2911. doi:10.1021/om980101u

25. Miyoshi, T.; Takeda, N.; Fukami, M.; Sato, S.; Ueda, M.; Miyata, O. Chem. Pharm. Bull. 2014, 62, 927-932. doi:10.1248/cpb.c14-00404

26. Boche, G.; Marsch, M.; Harbach, J.; Harms, K.; Ledig, B.; Schubert, F.; Lohrenz, J. C. W.; Ahlbrecht, H. Chem. Ber. 1993, 126, 1887-1894. doi:10.1002/cber.19931260820

27. Guo, L.; Wang, S.; Wei, Y.; Zhou, S.; Zhu, X.; Mu, X. Inorg. Chem. 2017, 56, 6197-6207. doi:10.1021/acs.inorgchem.7b00179

28. Chen, S.; Li, B.; Wang, X.; Huang, Y.; Li, J.; Zhu, H.; Zhao, L.; Frenking, G.; Roesky, H. W. Chem. - Eur. J. 2017, 23, 13633-13637. doi:10.1002/chem.201703804

29. Zhang, G.; Deng, B.; Wang, S.; Wei, Y.; Zhou, S.; Zhu, X.; Huang, Z.; Mu, X. Dalton Trans. 2016, 45, 15445-15456. doi:10.1039/c6dt02922a

30. Langer, J.; Krieck, S.; Görls, H.; Kreisel, G.; Seidel, W.; Westerhausen, M. New J. Chem. 2010, 34, 1667-1677. doi:10.1039/c0nj00136h

31. Zhu, X.; Zhou, S.; Wang, S.; Wei, Y.; Zhang, L.; Wang, F.; Wang, S.; Feng, Z. Chem. Commun. 2012, 48, 12020-12022. doi:10.1039/c2cc36045d

32. Zhu, X.; Wang, S.; Zhou, S.; Wei, Y.; Zhang, L.; Wang, F.; Feng, Z.; Guo, L.; Mu, X. Inorg. Chem. 2012, 51, 7134-7143. doi:10.1021/ic300137r

33. Kamnev, A. A.; Shchelochkov, A. G.; Tarantilis, P. A.; Polissiou, M. G.; Perfiliev, Y. D. Monatsh. Chem. 2001, 132, 675-681. doi:10.1007/s007060170081

34. Michaelis, A. Ber. Dtsch. Chem. Ges. 1894, 27, 244-262. doi:10.1002/cber.18940270150

35. Chokshi, R.; Fruasaha, P.; Kozak, J. A. Channels 2012, 6, 362-369. doi:10.4161/chan.21628

36. Murakami, S.; Suzuki, T. Method for producing boronic acid derivative, and novel boronic acid derivative. Eur. Pat. Appl. EP2886548A1, June 24, 2015.

37. McGough, J. S.; Cid, J.; Ingleson, M. J. Chem. - Eur. J. 2017, 23, 8180-8184. doi:10.1002/chem.201702060

38. Li, Y.; Wang, W.-H.; He, K.-H.; Shi, Z.-J. Organometallics 2012, 31, 4397-4400. doi:10.1021/om300284t

39. Campeau, L.-C.; Parisien, M.; Jean, A.; Fagnou, K. J. Am. Chem. Soc. 2006, 128, 581-590. doi:10.1021/ja055819x

40. Potavathri, S.; Pereira, K. C.; Gorelsky, S. I.; Pike, A.; LeBris, A. P.; DeBoef, B. J. Am. Chem. Soc. 2010, 132, 14676-14681. doi:10.1021/ja107159b 
41. Yen, F.-W.; Chang, C. H.; Teng, C.-M. Indenotriphenylene-based derivative for organic electroluminescent device. Eur. Pat. Appl. EP3059773A1, Jan 22, 2018.

42. Hongtao, F.; Yanrui, L.; Xing, W. Indole derivative an application thereof to organic electroluminescence. Chin. Pat. Appl. CN104725296A, June 24, 2015.

43. Han, S. I.; Kim, Y. B.; Kim, H. M. Preparation of fused heterocyclic compounds for organic electroluminescent devices. Kor. Patent KR2016077940A, July 4, 2016.

44. Igarashi, T.; Yagi, K. Organic electroluminescent device, and new indole derivative. Jap. Patent JP2009076834, April 9, 2009.

45. Zhang, F.; Wu, D.; Xu, Y.; Feng, X. J. Mater. Chem. 2011, 21, 17590-17600. doi:10.1039/c1jm12801a

46. Showell, G. A.; Mills, J. S. Drug Discovery Today 2003, 8, 551-556. doi:10.1016/s1359-6446(03)02726-0

47. Franz, A. K.; Wilson, S. O. J. Med. Chem. 2013, 56, 388-405. doi:10.1021/jm3010114

48. Ball, L. T.; Lloyd-Jones, G. C.; Russell, C. A. Science 2012, 337, 1644-1648. doi:10.1126/science.1225709

49. Denmark, S. E.; Baird, J. D. Chem. - Eur. J. 2006, 12, 4954-4963. doi:10.1002/chem.200600034

50. Langkopf, E.; Schinzer, D. Chem. Rev. 1995, 95, 1375-1408. doi:10.1021/cr00037a011

51. Cai, Y.; Qin, A.; Tang, B. Z. J. Mater. Chem. C 2017, 5, 7375-7389. doi:10.1039/c7tc02511d

52. Tibbelin, J.; Wallner, A.; Emanuelsson, R.; Heijkenskjöld, F.; Rosenberg, M.; Yamazaki, K.; Nauroozi, D.; Karlsson, L.; Feifel, R.; Pettersson, R.; Baumgartner, J.; Ott, S.; Ottosson, H. Chem. Sci. 2014, 5, 360-371. doi:10.1039/c3sc52389f

53. Klare, H. F. T.; Oestreich, M.; Ito, J.-i.; Nishiyama, H.; Ohki, Y.; Tatsumi, K. J. Am. Chem. Soc. 2011, 133, 3312-3315. doi:10.1021/ja111483r

54. Toutov, A. A.; Liu, W.-B.; Betz, K. N.; Fedorov, A.; Stoltz, B. M.; Grubbs, R. H. Nature 2015, 518, 80-84. doi:10.1038/nature14126

55. Du, W.; Kaskar, B.; Blumbergs, P.; Subramanian, P.-K.; Curran, D. P. Bioorg. Med. Chem. 2003, 11, 451-458. doi:10.1016/s0968-0896(02)00437-6

56. Bell, B. M.; Clark, M. B., Jr.; Devore, D. D.; De Vries, T. S.; Froese, R. D.; Gray, K. C.; Jackson, D. H. K.; Kuech, T. F.; Na, H.-Y.; Kearns, K. L.; Lee, K.-J.; Mukhopadhyay, S.; Rachford, A. A.; Spencer, L. P.; Woodward, W. H. H. ACS Appl. Mater. Interfaces 2017, 9, 13369-13379. doi:10.1021/acsami.7b00208

57. Cho, I.; Jeon, N. J.; Kwon, O. K.; Kim, D. W.; Jung, E. H.; Noh, J. H.; Seo, J.; Seok, S. I.; Park, S. Y. Chem. Sci. 2017, 8, 734-741. doi:10.1039/c6sc02832b

58. Frenzel, A.; Herbst-Irmer, R.; Klingebiel, U.; Noltemeyer, M.; Rudolph, S. Main Group Chem. 1996, 1, 399-408. doi:10.1080/13583149612331338727

59. Ohshita, J.; Lee, K.-H.; Kimura, K.; Kunai, A. Organometallics 2004, 23, 5622-5625. doi:10.1021/om049656h

60. Chen, Q.-A.; Klare, H. F. T.; Oestreich, M. J. Am. Chem. Soc. 2016, 138, 7868-7871. doi:10.1021/jacs.6b04878

61. Yonekura, K.; Iketani, Y.; Sekine, M.; Tani, T.; Matsui, F.; Kamakura, D.; Tsuchimoto, T. Organometallics 2017, 36, 3234-3249. doi:10.1021/acs.organomet.7b00382

62. Han, Y.; Zhang, S.; He, J.; Zhang, Y. J. Am. Chem. Soc. 2017, 139, 7399-7407. doi:10.1021/jacs.7b03534

63. Han, Y.; Zhang, S.; He, J.; Zhang, Y. ACS Catal. 2018, 8, 8765-8773. doi:10.1021/acscatal.8b01847
64. Brookhart, M.; Grant, B.; Volpe, A. F., Jr. Organometallics 1992, 11 , 3920-3922. doi:10.1021/om00059a071

65. Yu, J. O.; Lam, E.; Sereda, J. L.; Rampersad, N. C.; Lough, A. J.; Browning, C. S.; Farrar, D. H. Organometallics 2005, 24, 37-47. doi:10.1021/om0401004

66. Wassenaar, J.; de Bruin, B.; Siegler, M. A.; Spek, A. L.; Reek, J. N. H.; van der Vlugt, J. I. Chem. Commun. 2010, 46, 1232-1234. doi:10.1039/b917632b

67. van de Watering, F. F.; van der Vlugt, J. I.; Dzik, W. I.; de Bruin, B.; Reek, J. N. H. Chem. - Eur. J. 2017, 23, 12709-12713. doi:10.1002/chem.201702727

68. van de Watering, F. F.; Stroek, W.; van der Vlugt, J. I.; de Bruin, B.; Dzik, W. I.; Reek, J. N. H. Eur. J. Inorg. Chem. 2018, 1254-1265. doi:10.1002/ejic.201701209

69. Barbier, M.; Devys, M. J. Heterocycl. Chem. 1989, 26, 265-267. doi:10.1002/jhet.5570260148

70. Devys, M.; Barbier, M. Synthesis 1990, 214-215. doi:10.1055/s-1990-26834

71. Torreilles, J.; Guérin, M.-C.; Previero, A. Biochimie 1985, 67, 929-947. doi:10.1016/s0300-9084(85)80289-3

72. Devys, M.; Barbier, M.; Loiselet, I.; Rouxel, T.; Sarniguet, A.; Kollmann, A.; Bousquet, J.-F. Tetrahedron Lett. 1988, 29, 6447-6448. doi:10.1016/s0040-4039(00)82369-2

73. Wincent, E.; Shirani, H.; Bergman, J.; Rannug, U.; Janosik, T. Bioorg. Med. Chem. 2009, 17, 1648-1653. doi:10.1016/j.bmc.2008.12.072

74. Shirani, H.; Janosik, T. J. Org. Chem. 2007, 72, 8984-8986. doi:10.1021/jo701627g

75. Janosik, T.; Bergman, J. Heterocycles 2002, 57, 1273-1278. doi:10.3987/com-02-9477

76. Shirani, H.; Stensland, B.; Bergman, J.; Janosik, T. Synlett 2006, 2459-2463. doi:10.1055/s-2006-950427

77. Gao, D.; Sand, R.; Fu, H.; Sharmin, N.; Gallin, W. J.; Hall, D. G. Bioorg. Med. Chem. Lett. 2013, 23, 5503-5506. doi:10.1016/j.bmcl.2013.08.070

78. Dockendorff, C.; Gandhi, D. M.; Kimball, I. H.; Eum, K. S.; Rusinova, R.; Ingólfsson, H. I.; Kapoor, R.; Peyear, T.; Dodge, M. W.; Martin, S. F.; Aldrich, R. W.; Andersen, O. S.; Sack, J. T. Biochemistry 2018, 57, 2733-2743. doi:10.1021/acs.biochem.8b00292

79. Kamal, A.; Srinivasulu, V.; Murty, J. N. S. R. C.; Shankaraiah, N.; Nagesh, N.; Reddy, T. S.; Rao, A. V. S. Adv. Synth. Catal. 2013, 355 , 2297-2307. doi:10.1002/adsc.201300416

80. Hung, T. Q.; Dang, T. T.; Villinger, A.; Sung, T. V.; Langer, P. Org. Biomol. Chem. 2012, 10, 9041-9044. doi:10.1039/c2ob26489g

81. Chitra, S.; Paul, N.; Muthusubramanian, S.; Manisankar, P. RSC Adv. 2012, 2, 1432-1438. doi:10.1039/c1ra00878a

82. Shibahara, F.; Kanai, T.; Yamaguchi, E.; Kamei, A.; Yamauchi, T.; Murai, T. Chem. - Asian J. 2014, 9, 237-244. doi:10.1002/asia.201300882

83. Yang, Y.; Li, W.; Ying, B.; Liao, H.; Shen, C.; Zhang, P. ChemCatChem 2016, 8, 2916-2919. doi:10.1002/cctc.201600589

84. Hamashima, T.; Mori, Y.; Sawada, K.; Kasahara, Y.; Murayama, D.; Kamei, Y.; Okuno, H.; Yokoyama, Y.; Suzuki, H. Chem. Pharm. Bull. 2013, 61, 292-303. doi:10.1248/cpb.c12-00882

85. Li, Y.; Shi, L.-T.; Zhu, W.-Q.; Li, H.; Zhang, Q. Synlett 2018, 29, 1847-1850. doi:10.1055/s-0037-1609573

86. Šiaučiulis, M.; Sapmaz, S.; Pulis, A. P.; Procter, D. J. Chem. Sci. 2018, 9, 754-759. doi:10.1039/c7sc04723a

87. Hartke, K.; Teuber, D.; Gerber, H.-D. Tetrahedron 1988, 44 , 3261-3270. doi:10.1016/s0040-4020(01)85959-7 
88. Kaiser, D.; Klose, I.; Oost, R.; Neuhaus, J.; Maulide, N. Chem. Rev. 2019, 119, 8701-8780. doi:10.1021/acs.chemrev.9b00111

89. Fedorov, N. V.; Shevchenko, M. V.; Anisimov, A. V.; Viktorova, E. A. Chem. Heterocycl. Compd. 1985, 21, 624-626. doi:10.1007/bf00515059

90. Pietras, R. J.; Arboleda, J.; Reese, D. M.; Wongvipat, N.; Pegram, M. D.; Ramos, L.; Gorman, C. M.; Parker, M. G.; Sliwkowski, M. X.; Slamon, D. J. Oncogene 1995, 10, 2435-2446.

91. Ethier, S. P. J. Natl. Cancer Inst. 1995, 87, 964-973. doi:10.1093/jnci/87.13.964

92. Showalter, H. D. H.; Sercel, A. D.; Leja, B. M.; Wolfangel, C. D.; Ambroso, L. A.; Elliott, W. L.; Fry, D. W.; Kraker, A. J.; Howard, C. T.; Lu, G. H.; Moore, C. W.; Nelson, J. M.; Roberts, B. J.; Vincent, P. W.; Denny, W. A.; Thompson, A. M. J. Med. Chem. 1997, 40, 413-426. doi:10.1021/jm960689b

93. Nguyen, L. P.; Bradfield, C. A. Chem. Res. Toxicol. 2008, 21, 102-116. doi:10.1021/tx7001965

94. Wilshire, J. F. K. Aust. J. Chem. 1967, 20, 359-364. doi:10.1071/ch9670359

95. Abele, E.; Popelis, J.; Shestakova, I.; Domracheva, I.; Arsenyan, P.; Lukevics, E. Chem. Heterocycl. Compd. 2004, 40, 742-746. doi:10.1023/b:cohc.0000040769.55088.e3

96. Naidu, P. S.; Majumder, S.; Bhuyan, P. J. Mol. Diversity 2015, 19, 685-693. doi:10.1007/s11030-015-9605-3

97. Thurow, S.; Penteado, F.; Perin, G.; Alves, D.; Santi, C.; Monti, B.; Schiesser, C. H.; Barcellos, T.; Lenardão, E. J. Org. Chem. Front. 2018, 5, 1983-1991. doi:10.1039/c8qo00360b

98. Talukdar, R. Asian J. Org. Chem. 2019, 8, 88-92. doi:10.1002/ajoc.201800584

99. Engman, L.; Stern, D.; Pelcman, M.; Andersson, C. M. J. Org. Chem. 1994, 59, 1973-1979. doi:10.1021/jo00087a008

100.Wendel, A. Phosphorus, Sulfur Silicon Relat. Elem. 1992, 67, 405-415. doi:10.1080/10426509208045863

101. Marletta, M. A. J. Med. Chem. 1994, 37, 1899-1907. doi:10.1021/jm00039a001

102. Molina, J. A.; Jiménez-Jiménez, F. J.; Ortí-Pareja, M.; Navarro, J. A. Drugs Aging 1998, 12, 251-259. doi:10.2165/00002512-199812040-00001

103. Thorns, V.; Hansen, L.; Masliah, E. Exp. Neurol. 1998, 150, 14-20. doi:10.1006/exnr.1997.6751

104. Yang, C.-G.; Wang, J.; Jiang, B. Tetrahedron Lett. 2002, 43 , 1063-1066. doi:10.1016/s0040-4039(01)02331-0

105.van Baren, N.; Van den Eynde, B. J. Front. Immunol. 2015, 6, 34. doi:10.3389/fimmu.2015.00034

106. Ye, Z.; Yue, L.; Shi, J.; Shao, M.; Wu, T. J. Cancer (Wyoming, Aust.) 2019, 10, 2771-2782. doi:10.7150/jca.31727

107. Abdel-Magid, A. F. ACS Med. Chem. Lett. 2017, 8, 11-13. doi:10.1021/acsmedchemlett.6b00458

108. Cui, G.; Lai, F.; Wang, X.; Chen, X.; Xu, B. Eur. J. Med. Chem. 2020, 188, 111985. doi:10.1016/j.ejmech.2019.111985

109. Nakayama, M.; Tsubaki, T. Indole derivative and application thereof. Jap. Pat. Appl. 2008133225A, June 12, 2008.

110.Sharif, S.; Rucker, R. P.; Chandrasoma, N.; Mitchell, D.; Rodriguez, M. J.; Froese, R. D. J.; Organ, M. G. Angew. Chem., Int. Ed. 2015, 54, 9507-9511. doi:10.1002/anie.201502822

111.Bharadwaj, P. R.; Dubey, A. K.; Masters, C. L.; Martins, R. N.; Macreadie, I. G. J. Cell. Mol. Med. 2009, 13, 412-421. doi:10.1111/j.1582-4934.2009.00609.x
112. Murphy, M. P.; LeVine, H., III. J. Alzheimer's Dis. 2010, 19, 311-323. doi:10.3233/jad-2010-1221

113. Sreenivasachary, N.; Kroth, H.; Benderitter, P.; Hamel, A.; Varisco, Y.; Hickman, D. T.; Froestl, W.; Pfeifer, A.; Muhs, A. Bioorg. Med. Chem. Lett. 2017, 27, 1405-1411. doi:10.1016/j.bmcl.2017.02.001

114. Chai, Y.; Zou, M.; Zhu, M. New small molecule compound, its preparation method and the method using the compounds for treating/prevention HIV-1 aids infections. Chin. Pat. Appl. CN107089936A, Aug 25, 2017.

115.Black, D. StC.; Choy, A.; Craig, D. C.; Ivory, A. J.; Kumar, N. J. Chem. Soc., Chem. Commun. 1989, 111-112. doi:10.1039/c39890000111

116. Reddy, K. H. V.; Reddy, V. P.; Shankar, J.; Madhav, B.; Kumar, B. S. P. A.; Nageswar, Y. V. D. Tetrahedron Lett. 2011, 52, 2679-2682. doi:10.1016/j.tetlet.2011.03.070

117. Chen, L.; Fajer, A. N.; Yessimbekov, Z.; Kazemi, M.; Mohammadi, M. J. Sulfur Chem. 2019, 40, 451-468. doi:10.1080/17415993.2019.1596268

118.Jones, A. W.; Wahyuningsih, T. D.; Pchalek, K.; Kumar, N.; Black, D. StC. Tetrahedron 2005, 61, 10490-10500. doi:10.1016/j.tet.2005.08.048

119.Sokai, S.-I.; Kubo, A.; Katsuura, K.; Mochinaya, K.; Ezak, M. Chem. Pharm. Bull. 1972, 20, 76-81. doi:10.1248/cpb.20.76

\section{License and Terms}

This is an Open Access article under the terms of the Creative Commons Attribution License (https://creativecommons.org/licenses/by/4.0). Please note that the reuse, redistribution and reproduction in particular requires that the author(s) and source are credited and that individual graphics may be subject to special legal provisions.

The license is subject to the Beilstein Journal of Organic Chemistry terms and conditions: (https://www.beilstein-journals.org/bjoc/terms)

The definitive version of this article is the electronic one which can be found at: https://doi.org/10.3762/bjoc. 17.137 